Portland State University

PDXScholar

1976

\title{
A Study of Requests for Voluntary Admission to Oregon State Hospital
}

Julie Kern

Portland State University

Jeanne Miller

Portland State University

Alice Plummer

Portland State University

Follow this and additional works at: https://pdxscholar.library.pdx.edu/open_access_etds

Part of the Clinical and Medical Social Work Commons, Psychiatric and Mental Health Commons, Psychological Phenomena and Processes Commons, and the Social Work Commons Let us know how access to this document benefits you.

\section{Recommended Citation}

Kern, Julie; Miller, Jeanne; and Plummer, Alice, "A Study of Requests for Voluntary Admission to Oregon State Hospital" (1976). Dissertations and Theses. Paper 1866.

https://doi.org/10.15760/etd.1865

This Thesis is brought to you for free and open access. It has been accepted for inclusion in Dissertations and Theses by an authorized administrator of PDXScholar. Please contact us if we can make this document more accessible: pdxscholar@pdx.edu. 


\title{
A STUDY OF REQUESTS FOR VOLUNTARY ADMISSION \\ TO OREGON STATE HOSPITAL
}

\author{
by \\ JULIE KERN \\ JEANNE MILLER \\ ALICE PLUMMER
}

A practicum submitted in partial fulfillment of the requirements for the degree of

MASTER OF

SOCIAL WORK

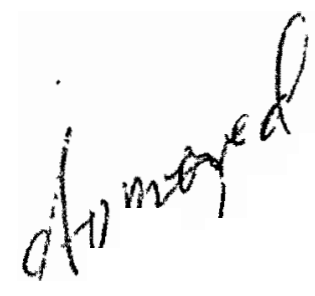

Portland State University

1976 
TABLE OF CONTENTS

PAGE

LIST OF TABLES • • . . . . . . . . . . . . . . .

CHAPTER

I PROBLEM AND FOCUS . . . . . . . . . . I

II REVIEW OF THE LITERATURE . . . . . . . 5

III METHODOLOGY . . . . . . . . . 22

Research Design . . . . . . . 22

Sample . . . . . . . . . . . 23

Data Gathering Procedures ..... 23

Statistical Procedure ....... 24

IV PRESENTATION OF THE DATA . . . . . . 26

A. Who Came ......... 26

Multiple Requests

Age of Requesters

Employment

Living Situation

B. Where Did They Come From . . . . 39

C. How Did They Come ....... . 42

Temporal Factors

D. Why Did They Come . . . . . . 45

Referral Source

Community Involvement

Treatment Other Than

Hospitalization

Previous Hospitalization

Admitting Physician 
E. Hospital Response . . . . . .

Collateral Contacts

Request Outcome

F. Dlagnosis.......... 67

V SUMMARY OF DATA ................... 74

A. Characteristics of the Population ........ . . 74

B. Summary of Demographic Data . . . 78

Difference Between Admitted and Refused Individuals Difference of First and Readmission Population

Demography Differentiated by Age

Demography Differentiated by Sex

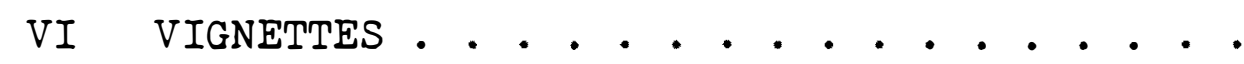

VII CONCLUSIONS . . . . . . . . . . .

Recommendations ......... . . 94

Implications For Further Study and Action . . . . . . . . . . 97 


\section{LIST OF TABLES AND GRAPHS}

TABLE

PAGE

I Sample Population by Type of Request

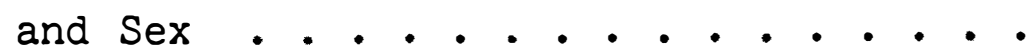

II Population Age . . . . . . . . . . 29

III Employment Status by Sex......... 31

IV Employment Status by Type of Admission

Request and Sex . . . . . . 32

$\mathrm{V}$ Living Situations of Males and Females

Requesting Admission to Oregon State

Hosp1tal . . . . . . . . . . .

VI Living Situation at Time of Request for

First Admissions and Readmissions,

by $\operatorname{sex} \cdot$. . . . . . . . . . . .

VII County of Residency by Average Miles

from Oregon State Hospital, Density,

Frequency and Per Cent . . . . . . .

VIII Transportation Assistance for Voluntary

Admissions to Oregon State Hospital .

42

IX Day of the Week Request for Admission

Was Made .. . . . . . . . . 44

$X$ Time of Day Request for Admission

Was Made . . . . . . . . . . 
TABLE

PAGE

XI Precipitating Incident of Men and Women,

First Admission and Readmission, of

Those Seeking Voluntary Admission . . .

47

XII Referral Source of First Admission and

Readmission of Men and Women Request-

ing Admission . . . . . . . . . . 54

XII Contact With Community Resources Prior

to Request for Admission . . . . . 56

XIV Treatment Other Than Hospitalization . . . 58

XV Date of Last Hospitalization . . . . . . 61

XVI Number of Previous Hospitalizations . . . . 62

XVII Collateral Contacts and Result of

Admission Request . . . . . . . . . 64

XVIII Diagnosis of Those Requesting Admission,

Males and Females, First and Readmis-

sion . . . . . . . . . . . . .

68

GRAPH

1 Graph of Age by Sex and Percentage . . . . 


\section{CHAPTER I}

\section{PROBLEM AND FOCUS}

This study was undertaken in February and March of 1975 in order to provide in depth analysis of those seek1ng hospital admission. It is a descriptive study of requests for voluntary admission to Oregon State Hospital. Special care was taken to incorporate the study in such a way that the current admitting procedures would not be rearranged or changed in any way. Essentially the study asks the questions:

Who makes self-requests for hospitalization?

Where do they come from? When? How do they get there?

Why do they come?

What is the history of their contact with other community agencies for service or previous hospitalization?

How does the hospital respond to the requests?

In order to better understand the dynamics of the requesting population, attention was focused on:

The possible differences between those individuals admitted and those denied admission.

The comparisons of requests for first admission and readmission.

The relationship of age and sex differences to the other findings in the study. 
The study made no attempt to describe treatment plans, modalities, the patients' length of stay, discharge procecedures or community follow-up.

A mentally 111 person is defined (Title 35, State of Oregon, 1973) as a person who because of a mental disorder is dangerous to himself or others, or unable to provide for his basic personal needs and is not recelving such care as is necessary for his health or safety.

Public concern for the care of mentally 111 persons was put into legislation in Oregon in 1880. One hundred thousand dollars was allocated to construct and furnish a "modified Italian bullding" to house the oregon State Insane Asylum in Salem. In October, 1883, 268 men and 100 women were moved to the new asylum from Dr. Hawthorne's East Portland facility in special rallroad cars. The original bullding, supplemented by many additions, other buildings and a campus, is still in use.

Construction of two more state hospitals, the introduction of psychotropic drugs and the concept of community care has reduced the patient population from its all time high of 3,500 in 1957 to the present 600. Just as changes in the social fabric of American 11 fe have occurred, so have changes in the hospital's name, procedures, treatment and patient population. 
Originally, commitment to the hospital was made by the patient's family or the community. This process has become court controlled as a protection for the unwilling individual. Currently, however, the large majority of patients at Oregon State Hospital are self-committed. In 1974, 1,046 patients were voluntarily committed and 660 were court committed (Booth 1974). When it is noted that of the court commitments, ninety-nine were criminal court commitments from all areas of the state to the only maximum security wards in Oregon, the proportion of voluntary to court commitments at oregon State Hospital is high indeed.

Studies have shown that admission to a psychiatric hospital will thereafter define an individual as possessing mental 1llness. His life and self-concept will never again be the same. It has also been shown that the large majority of Individuals admitted will establish repeated and frequent hospitalization.

The policy of the Division of Mental Health of Oregon is to reduce hospital population and to provide mental health services for individuals in their home community. Hospital staff look for ways to break the rehospitalization cycle. Still, individuals come in greater numbers and more often each year, requesting hospital commitment.

Knowledge of the characteristics of the self-requests for admission are therefore essential in order to design 
services that will positively rather than adversely affect the requester's condition.

The admission procedure at the time of the study centered around the recommendation of the physician. If the admission request came between the hours of $7: 30 \mathrm{a} . \mathrm{m}$. and 4:00 p.m., It was handled by the community ward that was assigned to the catchment area of the patient's home county. The request was processed directly on the ward with the physician interviewing the applicant and making the dispositional decision.

If the individual came to the hospital after 4:00 p.m. or on Saturday, Sunday, or a hollday, the admission request was handled by the physician on assigned and rotated duty at the administration bullding. No distinction was made between staff physicians and residents. They all rotated, having total responsibility on their duty assignment. 
CHAPTER II

\section{REVIEW OF THE LITERATURE}

A survey of the literature shows an increasing interest in the problem of admission and readmission to mental hospitals. Between the years of 1956-1966, three developments--tranquilizing drugs, the therapeutic commun1ty and geographic decentralization of large state mental hospitals--worked together to inaugurate closer working relationships with the community and lower the hospital census ( $\mathrm{Bloom}$ 1973, p. 6).

However, studies done in many parts of the country since then (Franklin 1975, Rosenblatt 1974, Gurel 1972, DiScipio 1973, Weinstein 1973) report the trend of an increased number of hospitalizations with greater frequency. Stays of shorter duration still hold down the patient population from the all time highs of the mid-fifties, but the emerging hospitalization pattern is frequently referred to as a "revolving door" with the same people being circuited in and out.

The presence of community mental health clinics does not seem to lessen the need for hospitalization. Decker (1974) reports that in Alabama there are higher rates of hospitalization, and per capita income, in counties with 
community mental health centers. Franklin (1975) also cites hospital readmission patients having had more contact with community mental health clinics than the patients who were followed in his study and did not return to the hospital. Oftentimes hospitalization does not relate to the patient's symptoms or their severity. Miller (1966, p. 38) described a study that was done in California which supported the notion that it was not the existence of symptoms or of their severity but the lack of social support systems that resulted in hospitalization. In this study where over 71 per cent of the hospital patients returned once in five years and 24 per cent an average of 4.4 times, 1 t was concluded that the returns had little to do with the symptom or severity of the disease but everything to do with the lack of support former patients found in their communities. Very often a released patient had no belief in his ability to "make $1 t$ " and the hospital experience reinforced his certainty that he would not. The 20 per cent of the patients who left the hospital with no after-care, medication or contact, that resisted patient identity in the hospltal were much more successful in staying out. Miller states this does not mean that after-care is not needed but that something beyond psychiatric help, something more important, more directly to do with "world bullding" is needed. 
The NIMH study done in Denver, 1965-1968, reported by Flomenhaft, et al. (1969), gave support to community/familyoriented treatment and also touched on the difficulty of keeping some individuals out of the hospital. In this study 150 individuals requesting admission were randomly selected and kept out of the hospital. They were treated with outpatient services from a family treatment unit. The patient and his family were told that the problem was manageable; that many others had been helped in this way; that psychotic behavior was seen as a regressive form of communication, and that a full return to work was expected. They used interviews, twenty-four hour avallability, home visits within twenty-four hours, and drugs for the patient and other members of the family if needed.

The staff further offered occasionally a holding-bed in the emergency room for a few hours and postcrisis contact with relevant referral processes. This experimental group was compared to a control group that was granted admission. There were 150 in each group. The two groups were followed with a collection of baseline data and interviews six months and eighteen months after treatment. The experimentals did as well as the controls in their function and returned to prestress function faster at much less cost.

Appropriately, the same number of experimentals' as controls (fourteen - sixteen) returned to the hospital 
within six months. The report of the study notes that with each hospitalization the patient and family's image were continually altered adversely. The family treatment unit found that when (1) family disequilibrium was not recent; (2) the original sources of discord forgotten and impasses in the family common, and (3) resistence expressed by missed appointments, the team would not win the power struggle to keep the patient out.

The problem of readmission is examined by countless studies. In Rosenblatt and Mayer's (1970) review of past studies of mental patients' recidivism, the concensus among researchers was that pathology and symptoms were not rel1able indicators of patient return, nor was the length of time a patient spent in the hospital. The number of previous admissions and the history of employment were the only indicators upon which future predictions could be made. Lorel and Gurel (1973), after several studies into recidivism, make the statement: "Readmission is essentially an arbitrary criterion, not at all related to the patient's condition and future attempts to predict it should be abandoned."

Eaton (1974) concludes on the basis of following the admission pattern of schizophrenics, that it cannot be said that their admission is the result of positive or negative 
reinforcement in previous hospital experiences but a result of a cluster of heterogeneity in causes.

Buell and Anthony (1973) found that the patlent's past employment record combined with the record of previous hospitalizations were reliable indicators. DiScipio (1973) concurred.

Franklin, et al. (1975) followed 104 patients selected at random among those discharged from a southern state mental hospital in 1972. They found that those who returned to the hospital most frequently were divorced, single or separated; recelved income from other than their own employment; had fewer leisure time activities; were more likely to have a drinking problem, and had more contact with the community mental health center after discharge than the patients in their study who stayed out of the hospital during the follow-up period.

Wanklin, in Canada, as early as 1955, also showed the relationship between unemployment, marital status and hospitalization. IInn and Lawrence (1969) found that those who held the most favorable expectations of their hospitalization were the noncoerced, single, urban male alcoholic and the most negative expectations were held by the married, rural female, whether coerced or not. They report that females usually saw the hospitalization not as relief or help with their problems, but as one more problem to deal with. 
Iinn and Lawrence stated that these conditions prevalled whether or not there was physical deterioration or social isolation involved.

Although Scheff (1966), Goffman (1961) and others. see the hospital as creating and perpetuating the dependency that brings patients back to $1 t$, the studies quoted seem to indicate that the patterns of dependency--being without internal or environmental supports--is already established in many patients and that the hospital and community mental health centers are left to respond to many individuals with no other place to turn.

The Braginskys (1973) write of this problem:

The mental-health professional's view of the hospital is also out of focus. The hospital cannot control its gates (in either direction) or intervene effectively in the lives of its residents. A clear picture would show the hospital as another place where people can visit or settle down; that is, a community. In recent years mental health professionals have tried to integrate the hospital into outside community life. Mental patients have been doing just that for years... Some words of caution are necessary . . . It is important to keep in mind that the parallel we have drawn between a mental hospital and a resort is not based on similarities in the quality of life. Clearly, a mental hospital is a poor man's last resort. The similarities are in life styles. Both settings impose minimal external demands, offer similar physical facilities (swimming pools, dances, movies) do not expect the residents to be productive, allow the residents freedom to choose how they will spend their time, and are installations to refresh and refurbish the residents. Both settings are meant to reduce stress and tension... As we have demonstrated, achieving and maintaining the status of a mental patient is the result of purposive 
behavior rather than a hapless consequence of mental 1llness. Given the life circumstances of most long-term patients, their choice of career is realistic and rational. Indeed, the mental hospital is the only alternative (other than perhaps, prison) available to the lower-income person who cannot--or simply does not want to--make it in mainstream society. Hospitalization, then, tells us more about social conditions than about mental conditions.

Rosenblatt (1974) postulates that the more appealing and the closer the hospital is relative to the home environment, the more patients will shuttle in and out of 1t. He reports that many come for its shelter and amenities, not for the promise of treatment and intervention. The Braginskys (1969) report that there is often an active avoldance of the physiclans and therapy groups. In one of their many studies, patients spoke of their knowledge that the more inconspicuous a patient is to the physicians and "upper staff" and the more cooperative he is with the aldes in participating in routines and requirements, the longer he gets to stay. The Braginskys (1969, p. 50) found that patients learn many counterpower strategies and exercise self-determination in their dally routines, even if schizophrenic.

Rosenblatt speaks of the shuttling back and forth of patients from hospital to outside as being in part due to the staff making long-term patients, whose lifestyle they can't influence, so unwelcome that they stay for only a short time. Similarly, on the outside the patients' lack of 
welcome makes them remember the peacefulness of the hospital and the fact that they were not unhappy there, thus making a quick return.

There are some indications that a trend toward longer hospital stays has started. Weinstein (1973) reports that in New York State the lengths of stays have increased since 1971. Singer (1975) wrote that her follow-up study in a private psychiatric facility, contrary to common belief, revealed that long-term patients were doing better than the patients who were hospitalized for short periods of time. The long-term schizophrenic patients showed the greatest improvement in the adjustment outside the hospital, the short-term patients with personality disorders showed the least improvement. The question can be raised as to whether the difference in adjustment was due to the length of stay in the hospital or to the differences in their problem. An Oregon State Hospital document (1975). reported indications of longer stays, the causative factors having to do with the lack of facilities for some patients on the outside.

Franklin (1975) writes of some mental health specialists beginning to question the validity of using readmission to assess the effectiveness of community mental health centers. These professionals point out that as the average 
length of stay decreases, it may be desirable to provide periods of respite for the mentally 111 to compensate for the briefer period of treatment that patients receive.

Talbott presents a different view. He reports a study that followed one hundred readmissions in the MeyerManhattan Psychiatric Center in New York during 1971. It was judged that of the one hundred readmissions, only sixteen were absolutely necessary. These had to do with symptom progression, deterioration, regression, homocidal, suicidal, psychosocial difficulties. The eighty-four that were avoidable needed a variety of services that could have been provided with more involvement with the family and community agencies before or after the requests and in making minor improvements in existing services, necessitating no extra expenditure of money. The service needs for the eighty-four were: seventeen, vocational counseling; seven, sheltered workshops; thirteen, structured living situations; four, group therapy; nine, family therapy; eighteen, home visiting; seven, crisis intervention; six, day centers; four, night hospital; four, social clubs; three, services for the elderly; three, halfway houses.

Smith (1963) writes that of the requests for hospitalization in one hundred schizophrenic patients, the family decisions to hospitalize seemed to result from instances that aroused strong fear, shame or disgust in the families. 
In twenty-three cases the patient committed some act; e.g., carved in the new piano top, appeared nude in public, hit someone, or was "about to do something." She recommended that means be established to provide families with help before the "last straw" incident occurred.

Mendel, et al. (1969, p. 101) studies the admissions procedure itself in a large state hospital. They noted that the support system and attitude of those in charge of the process could play a critical role in the outcome. Paradoxically many of the decision-making persons did not recognize or choose to exercise their influence on the outcome of an admission request. This study noted that psychiatric residents having less than six months' experience hospitallzed more than any other admitting staff. Experienced social workers hospitalized fewer individuals than any other admitting staff. Mendel supported the finding of other studies, previously cited, that the severity of symptoms usually did not determine the decision to hospitalize. On the basis of their study, Zwerling and Karauit (1975) believed that it was easier for the admitting staff to fill out a form and send the requester along to a ward than to sit and talk to him about his problem.

Rosenhan (1973) reports on the experiment he designed in which elght sane people gained admission to twelve 
different hospitals. He describes their diagnostic experlences and experiences in the institutions:

After calling the hospital for an appointment, the pseudo-patient arrived at the admissions office complaining that he had been hearing volces. Asked what the volces sald, he replied that they were often unclear, but as far as he could tell they sald "empty," "hollow" and "thud." The volces were unfamiliar and were of the same sex as the pseudopatient. The cholce of these symptoms were occasioned by their apparent similarity to existential symp toms.

Beyond alleging the symptoms and falsifying name, vocation, and employment, no further alterations of personal history were presented as they had actually occurred. Relationships with parents and siblings, with spouse and children, with people at work and in school, consistent with the aforementioned exceptions, were described as they were or had been. Frustrations and upsets were described along with joys and satisfactions. These facts are important to remember. If anything, they strongly biased the subsequent results in favor of detecting sanity, since none of their histories or current behaviors were seriously pathological in any way

Apart from that short-lived nervousness (upon admission to the ward and getting over the fear of being detected), the pseudopatient ceased simulating any symptoms of abnormality. He spoke to patients and staff as he might ordinarily. When asked by staff how he was feeling he indicated that he was fine, that he no longer experienced symptoms. He responded to instructions, calls for medication (which were not swallowed) and dining-hall instructions. He spent his time writing down his observations about the ward, its patients and the staff. Initially these notes were written "secretly," but as it soon became clear that no one much cared, they were written on standard tablets in such public places as the dayroom...

The pseudopatient entered a hospital with no foreknowledge of when he would be discharged. Each 
was told that he would have to get out by his own devices, essentially by convincing the staff that he was sane. The psychological stresses assoclated with the hospitalizations were considerable, and all but one of the pseudopatients desired to be discharged almost immediately after being admitted. They were, therefore, motivated not only to behave sanely, but to be paragons of cooperation. That their behavior was in no way disruptive is confirmed by nursing reports, which have been obtained on most of the patients. These reports uniformly indicate that the patients were "friendly," "cooperative" and "exhibited no abnormal indications."

Despite this public "show" of sanity, the pseudopatients were never detected. Admitted, except in one case, with a diagnosis of schizophrenia, each was discharged with a diagnosis of schizophrenia "In remission" . . . Length of hospitalization ranged from 7 to 52 days, with an average of 19 days. The pseudopatients were not, in fact, carefully observed, but this fallure clearly speaks more to traditions within psychiatric hospitals than to lack of opportunity.

Rosenhan also described a related experiment in a research and teaching hospital whose staff had heard of his finding and doubted that such an error could occur in their hospital. They were told that within the next three months one or more pseudopatients would attempt to be admitted. Each staff member was asked to rate each patient who presented himself at admissions or on the ward according to the likelihood that the patient was a pseudopatient. Judgments were obtained on 193 patients. Forty-one patients were alleged, with high confidence, to be impostors by at least one member of the staff. Twenty-three were considered suspect by at least one psychiatrist. Nineteen were suspected 
by one psychiatrist and one other staff member. Actually, no genuine pseudopatient, at least from Rosenhan's group, presented himself during the period. The author of the experiment comments, "Any diagnostic process that lends itself so readily to massive errors of this sort cannot be a very reliable one."

Jerold Maxmen and Gary Tucker (1973) present a different emphasis. They suggest that there is a growing prejudice among mental health professionals against hospitalization and report five cases where earlier admissions could have saved the patient and family suffering. They do see flaws in the admission procedure as practiced. They propose that a two-stage admission process be used which would include a discriminating preadmission screening and work-up. Their observations showed that admission is seldom tied to goals, and pointed out that the common admitting note "for evaluation and treatment" is meaningless. The work-up should include an assessment that determines whether a patient's problem is intrapsychic, situational, or of family pathology.

Rabiner (1974) agrees that in many situations a patient is greatly benefited by hospital treatment and that it is often less costly than outpatient care. He reports three cases to validate his claim. 
Greenblatt (1971) writes of the changes put into effect in the Boston Hospital that were based on research and recommended research based data to be used in all parts of hospital reorganization. A student research project revealed that patients coming to the hospital often had to walt three hours to be seen, were ignored by all while they waited, examined with little privacy, and when admitted, given no explanations as to why things were taken away from them, where they were going or why. On the ward they were not introduced or given any orientation. The hospital responded to the research by assigning their most experienced staff to handle admissions, postponed admission until a period of one to five days of observation and screening, and put the admission and screening facilities into new quarters under outpatient status.

Olin and olin (1975) found voluntary hospital patients in their study were often confused about their rights. For the most part they did not know that they had to give seventy-two hours' notice of intent to leave. Although the information was given at the time of admission, the patient did not retain it and after a few days kept asking the question, "How do I get out?" When patients had the answers to that question, they were usually ready to deal with questions of "What can I get out of being here?" The authors found that patients oriented fast if given a chance. 
Thomas Szasz (1972) calls voluntary hospitalizations an unacknowledged practice of fraud. He mentions the common practice of giving patients cholces of elther coming into the hospital or going to jail. He also belleves that as long as any restriction is placed on any inmate or any restriction placed on his leaving, he does not truly have "voluntary" status.

The Portland Oregonian ran a series of articles January 28th to March 3, 1976 covering recent developments in oregon around the issue of involuntary commitments. They report that as the result of legislation, new "patients' rights" groups, greater participation of lawyers in the process and sensitized public opinion against abuses, changes are occurring that will decrease the number of involuntary commitments. Our study is interested in these changes because of the implications they have for voluntary admissions.

Blachly (Oregonian, March 3, 1976, p. Al9) offers the view of a physician:

We see loved ones and neighbors who sincerely wish to get the best treatment for their loved ones being placed on the witness stand and subjected to all the rigors of cross-examination. Accusations must be stated in lurid detail and feeling and the potential for rehabilitation that perhaps could be mended are forever shattered. We have seen it become necessary for a person who wishes to get help for a loved one to get his own attorney in order to deal with the legal circumlocutions.... 
In the same paper Crawshaw, another physician, writes:

- . the special reason I'm interested, in the treatment of prisoners at Rocky Butte . . . 3 men in 7x9-foot cages, twenty-three hours a day ... is that the commitment laws in Oregon have been so changed that it's no longer possible to effectively hold a mentally disturbed person as a patient, and consequently they are being held as prisoners. The tragedy at Rocky Butte is that we have 155 men in the $A$ and $B$ blocks who are absolutely in need of psychiatric help... Some are mad in the oldfashioned way, with hallucinations and delusions, screaming to Christ about Hitler, some are mad in the fashion of "too dangerous for society" and not a one is being treated as a human being let alone as a patient. How can this be possible?.. . It's simple: The civil libertarians and reformers have cleaned up the "commitment mess" and the state hospital is no longer the recipient of men "with

rights." There is nothing like a zealous, selfrighteous reform movement to get us back where we started from.

In an article entitled "The Criminalization of Mentally Disordered Behavior," Abramson (1972) writes of a - similar situation in California. He states that the drug abusers, borderline psychotics or character disordered individuals brought to the hospital by someone else can only be held up to seventy-two hours on an emergency hold. If physicians cannot get an involuntary commitment for the patient who does not want to stay in the hospital, or the physician is unwilling to start treatment on a voluntary basis because this population has a pattern of frequent leave-taking against medical advice--the patient will have to be started through the courts and jails. 
Zwerling and Karauit (1975) compared involuntary to voluntary patients in a state hospital. They observed more voluntary patients in their hospital. Most involuntary patients had previous psychiatric experience and were usually assaultive, schizophrenic, agitated, and came from the poor, black area of the Bronx. Almost none of the involuntary had alcohol or drug abuse diagnosis. The writer of the Oregon State Hospital study observed that over 30 per cent of the voluntary patients had a diagnosis of alcohol and drug abuse and were very dependent people.

With this background from the literature about the complexity of the problem, current practice and patterns of voluntary mental hospitalizations, we turn to the methodology and data of this study. 
CHAPTER III

METHODOLOGY

This study is an outgrowth of the combined interest of three social work students on fleld placement and the Social Service Department of the Oregon State Hospital. Interest developed because of the need for more detalled information regarding the individual requesting admissions to this hospital. The hospital staff, concerned with the high rate of voluntary admissions sought alternatives to better meet the needs of those seeking admission. In order to assess these needs the researchers designed a study in an effort to explore who came asking to be admitted, how they came, where they came from, why they came and what was the outcome. Aspects of the study included the research design, the sample, data gathering, statistical procedures, data processing, and a plan of literature research.

$\underline{\text { Research Design }}$

This study is descriptive and exploratory. It is descriptive of certain characteristics of 178 individuals who presented themselves for admission to Oregon State Hospital. 
Sample

The study sample included the entire population of those individuals requesting voluntary admission to oregon State Hospital during the fifty-nine day period of February and March of 1975. One hundred seventy-elght questionnalres were completed, involving 160 individuals with multiple requests from thirteen persons.

\section{Data Gathering Procedures}

A questionnaire was designed by the investigators and the Social Service Director. In light of time limitations, no pretesting of the questionnaire was administered. Questionnalres were filled out by the day admission clerk, the communications staff during evening and night shifts, and the investigators. Instruction for the completion of the questionnalre was done by meeting several times with the appropriate staff involved. Subsequent monitoring and tracking by these investigators was accomplished on a biweekly basis. This involved inspection of the completed questionnaires, a review of incompleted ones with the staff member responsible, and referral to patient records when necessary. Incompleted questionnaires were completed by the investigators by referring to patient records.

The questionnaire was designed to cover four areas of concern. First, to examine who came, the information of 
sex, age, employment and living situation were requested. Second, how they came, where from, and when they came were studied by asking who brought them, county of residence, and time and day of request. Third, why these people chose to request admission was dealt with by asking: was there a precipitating incident; was the individual referred; was there prior community contact; was there other community treatment; had the individual previous psychiatric hospitalization and if so, the number of hospitalizations and the date of the last hospitalization. Fourth, the outcome of the request for admission was examined by asking: were there collateral contacts made by hospital staff; what was the outcome of the request; and how was the problem described by the admitting physician.

Questions that asked: had the person access to a bed elsewhere; was the admitting physician familiar with the Individual; what information source did the admitting physiclan have; and who was the admitting physician, were, on examination of the data, discovered to be irrelevant to the purpose of the study and therefore not used. For a copy of the questionnaire, see the Appendix.

\section{Statistical Procedure}

When data collection was complete, hand tabulation was done by the investigators for preliminary study. Subsequently, coding, key punching, and programming for frequency 
and percentages were carried out. Following an examination of the data, card sorting was done to divide the population into males and females, first admissions and readmissions, as groupings. These categories were used as independent variables which were then cross tabulated with the dependent variables, times of day, day of week, county of residence for relationships. To test for the significance of the difference between those individuals applying for first admission and readmission, a $T$ test was used. Finally, to test for the deviation of an observed frequency from a theoretical frequency as with two dependent variables, a ch1-square was computed. 


\section{CHAPTER IV}

\section{PRESENTATION OF THE DATA}

The purpose of this section of the study is to present demographic data by means of analysis and tables using frequencies and percentages to describe the study sample. The study was conducted during the fifty-nine day period of February and March of 1975. One hundred seventy-eight questionnaires were completed; 152 of the individuals were admitted and twenty-six were denied admission.

\section{A. Who Came,}

The first portion of the data presentation answers the question, "Who came to Oregon State Hospital?" by analyzing characteristics of sex, age, employment and living situation. 
TABLE I

SAMPLE POPULATION BY TYPE

OF REQUEST AND SEX

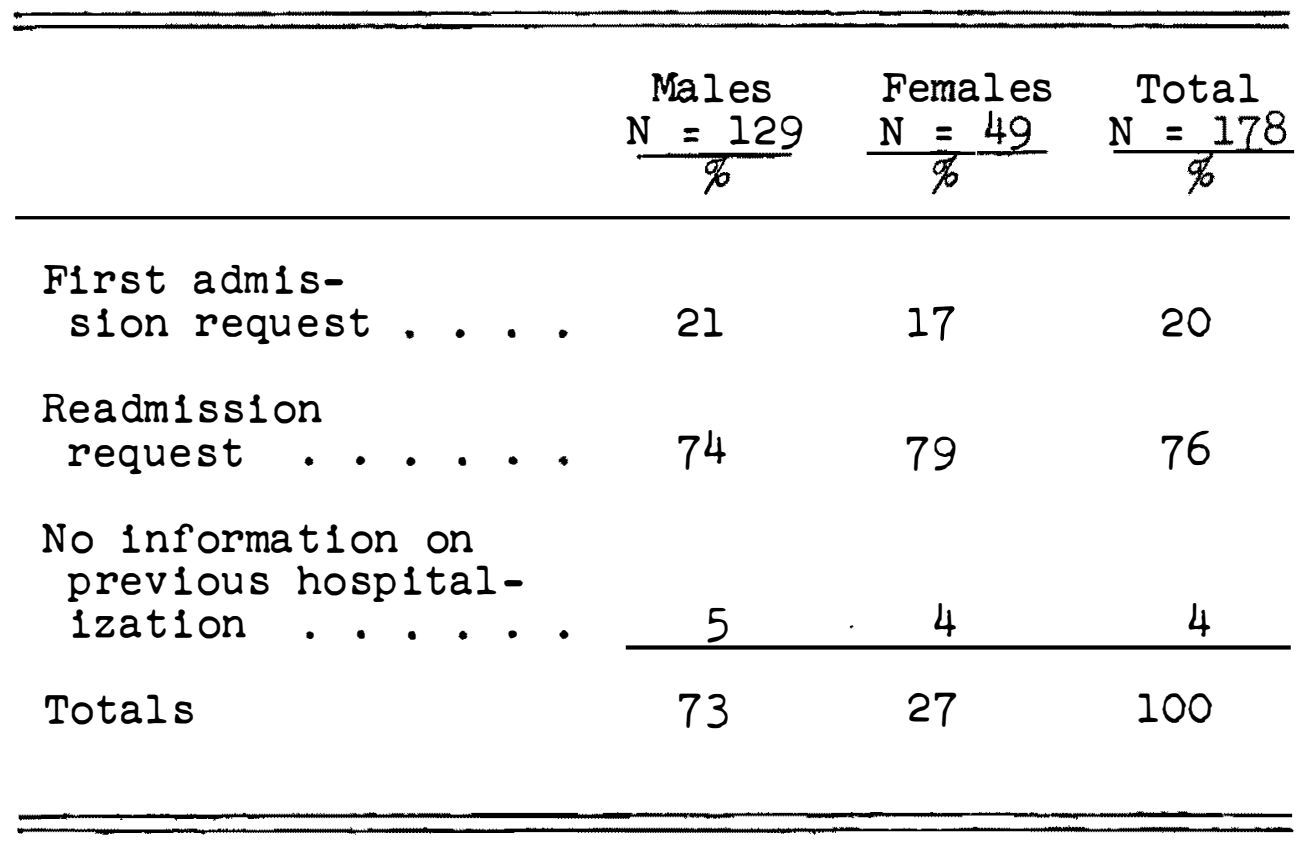

The Oregon State Hospital study population includes 27 per cent females and 73 per cent males. Table I examines the sex of the population with regard to first admission and readmissions. Twenty per cent of those individuals in the study were requesting their first psychiatric hospitalizat1on; among these were 21 per cent of the males and 17 per cent of the females. Seventy-six per cent of the population had been hospitalized before and were requesting readmission. Seventy-four per cent of the males fell into this category, as did 79 per cent of the females. 
Multiple Requests. An examination of the 178 requests revealed that thirty-one of these requests were made by thirteen individuals. These thirteen had previous oregon State Hospital hospitalization. One person made six requests and was refused twice, another made three requests and eleven made two separate requests, five of which were refused admission once. Of the thirteen requesting, eleven were men, two were women.

Age of Requesters. The ages of the individuals included in the study range from thirteen years to seventynine years. The median age was thirty-one and the modal age was twenty-three years.

Table II shows the age distribution by sex. Ten per cent of the persons in the study were twenty-one years of age and less; 20 per cent were in the twenty-one to twentyfive year old category, and 60 per cent were under the age of thirty-five. There is a noticeable decline in numbers of cases after the age of thirty-five. The highest percentage of the female population fell in the thirty-one to thirty-five year old grouping with 19 per cent, while the highest percentage of males was in the twenty-one to twentyfive year old grouping with 21 per cent. 
TABLE II

POPULATION AGE

\begin{tabular}{|c|c|c|c|}
\hline Age & $\begin{array}{c}\text { Males } \\
N=129 \\
\%\end{array}$ & $\begin{array}{l}\text { Females } \\
N=49 \\
\frac{\%}{\%}\end{array}$ & $\frac{\begin{array}{c}\text { Total } \\
\mathrm{N}=178\end{array}}{\%}$ \\
\hline $13-17$ & 4 & 0 & 3 \\
\hline $18-20$ & 5 & 12 & 7 \\
\hline $21-25$ & 21 & 17 & 20 \\
\hline $26-30$ & 15 & 15 & 15 \\
\hline $31-35$ & 13. & 19 & 15 \\
\hline $36-40$ & 9 & 6 & 9 \\
\hline $41-45$ & 9 & 8 & 9 \\
\hline $46-50$ & 12 & 2 & 9 \\
\hline $51-60$ & 9 & 11 & 6 \\
\hline $61-70$ & 7 & 4 & 6 \\
\hline $71+$ & 0 & 4 & 1. \\
\hline Unknown & 2 & 2 & 1 \\
\hline
\end{tabular}

Graph 1 shows the age distribution of the population in different form. The male population is younger than the female and there is a marked decline in age for both sexes after the age of th1rty-f1ve. 
GRAPH I

AGE BY SEX AND DISTRIBUTION

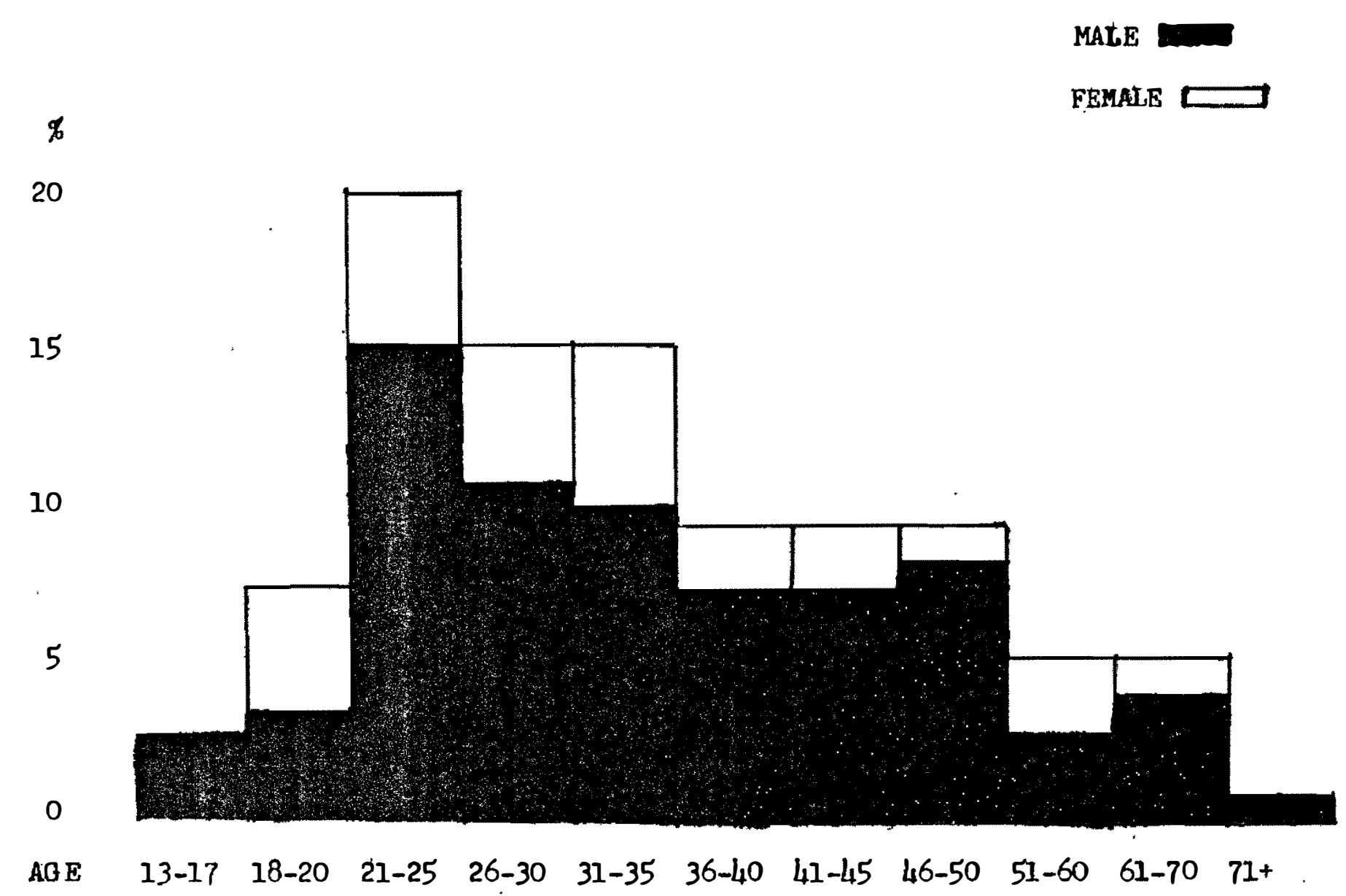


Employment. To further explore the question of "Who came to Oregon State Hosp1tal?" the employment status is examined for males and females at the time of first admission and readmission in Tables III and IV. A marked difference in employment is evident between the two groups of individuals making first admission requests and those making readmission requests. There is an overall high rate of unemployment among both males and females in the study, with the greatest percentage of unemployed and disabled among those requesting readmission.

TABIE III

EMPLOYMENT STATUS BY SEX

\begin{tabular}{|c|c|c|c|}
\hline & $\begin{array}{c}\text { Males } \\
\frac{N=129}{\%}\end{array}$ & $\begin{array}{l}\text { Females } \\
\frac{N=49}{\%}\end{array}$ & $\begin{array}{c}\begin{array}{c}\text { Total } \\
\mathrm{N}=178\end{array} \\
\% \%\end{array}$ \\
\hline Employed & 15 & 8 & 13 \\
\hline Unemployed & 73 & 73 & 73 \\
\hline Disabled & 4 & 6 & 4 \\
\hline Unknown & 8 & 13 & 10 \\
\hline Total & 100 & 100 & 100 \\
\hline
\end{tabular}


TABLE IV

EMPLOYMENT STATUS BY TYPE OF ADMISSION REQUEST AND SEX

\begin{tabular}{|c|c|c|c|c|}
\hline & $\frac{\text { Males }}{\text { First Admission }}$ & $\begin{array}{c}\text { Males } \\
\frac{\text { Readmission }}{N=96} \\
\frac{N}{\%}\end{array}$ & 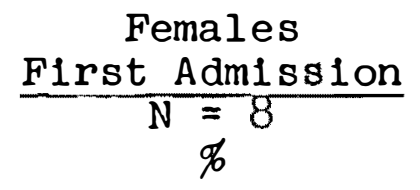 & $\begin{array}{c}\text { Females } \\
\frac{\text { Readmission }}{\bar{N}=39}\end{array}$ \\
\hline Employed & 26 & 13 & 25 & 5 \\
\hline Unempl oyed & 59 & 73 & 50 & 79 \\
\hline Disabled & 0 & 6 & 0 & 8 \\
\hline Unknown & 15 & 15 & 25 & 8 \\
\hline
\end{tabular}


Seventy-three per cent of the total sample population was unemployed, this included 73 per cent of the females and 73 per cent of the males as seen in Table III.* Table IV divides the population into first admission males and females and readmission males and females. Females requesting readmission had a higher unemployment rate of twenty-nine percentage points than first admission seekers. Males showed a similar trend with fourteen percentage points difference. The findings similarly show a lower percentage of employed males and females requesting readmission. Among the male population, 26 per cent of the first admission applicants were employed as compared to 13 per cent of the readmission applicants. Twenty-five per cent of the females making first admission requests were employed, while a smaller 5 per cent of those seeking readmission were employed. The same trend holds true for the category of the "disabled." While there were no disabled persons among the first admissions group, 6 per cent of the males and 8 per cent of the females in the readmission group were sald to be disabled. The relationship of age to employment shows the majority of the employed males to be thirty-five years of age or less,

* Categories for housewife and student were not used, therefore not differentiated, and were included in the category of unemployed. 
while the employed females were thirty-six years of age or older, a completely opposite trend. Fifty-six per cent of the unemployed males were under the age of thirty-five as were 51 per cent of the unemployed females.

Findings of this study show a high rate of recidivism and a high rate of unemployment among those individuals requesting admission to Oregon State Hospital. This information can be compared with Buell's findings in his study on recidivism (Buell 1973, pp. 361-65). His study revealed that previous hospitalization and past employment history are the biggest indicators for recidivism. Rosenblatt (1974), Franklin (1975), Winklin (1955), and Linn (1969) also concur with our findings of the relationship between unemployment and hospitalization.

Living situation. The following categories were chosen to describe living situations of each person in the study sample: independent home, in which the individual or spouse is the head of the household; nursing home; group home, which constitutes a facility for not less than six-bed capacity and is geared towards providing a program beyond meals and lodging; parental home in which the individual is related to family by blood or marriage. Finally, other living situations, which refer to any not defined above, 
including temporary arrangements such as missions, jails or half-way houses. Comparison of age with living situations showed no significant differences.

Examination of the living situation data shows the greatest percentage of the population in independent homes. There is a noticeably greater number of people living in parental homes, group homes and other situations at the time of readmissions than for those requesting first admission.

\section{TABLE V}

\section{LIVING SITUATIONS OF MALES AND FEMALES REQUESTING ADMISSION TO \\ OREGON STATE HOSPITAL}

\begin{tabular}{lccc}
\hline & $\begin{array}{c}\text { Males } \\
\frac{N=129}{\%}\end{array}$ & $\frac{N^{N}=49}{\%}$ & $\frac{N=178}{\%}$ \\
\hline Independent home & 41 & 68 & 49 \\
Nursing home & 1 & 2 & 1 \\
Parental home & 20 & 6 & 16 \\
Group home & 9 & 4 & 8 \\
Other situation & 24 & 13 & 15 \\
Unknown & 5 & 3 & 5 \\
\hline - & & & \\
\hline
\end{tabular}


Table VI looks at the living situation using males and females as the independent variables. Forty-nine per cent of the total population were living in independent homes at the time they requested admission to Oregon State Hospital. Significantly, 41 per cent were men compared to 68 per cent women.

Of the total population, 16 per cent lived in parental homes. Twenty per cent of the males lived with their parents; over half of these were twenty-six years of age and older. Few women lived in the home of their parents. Group home living accounted for 8 per cent of the study sample with 9 per cent of the males and 4 per cent of the females. Fifteen per cent of the population had "other living situation," with four times as many men as women in this category . 
TABLE VI

LIVING SITUATION AT TIME OF REQUEST FOR FIRST

ADMISSIONS AND READMISSIONS, BY SEX

\begin{tabular}{|c|c|c|c|c|}
\hline & $\begin{array}{c}\text { Males } \\
\frac{\text { First Admission }}{N}=27 \\
\not \mathscr{t}\end{array}$ & $\begin{array}{c}\text { Females } \\
\frac{\text { First Admission }}{\mathrm{N}=8} \\
\frac{\phi}{\phi}\end{array}$ & $\begin{array}{c}\text { Males } \\
\frac{\text { Readmission }}{N=96} \\
\% \%\end{array}$ & $\begin{array}{c}\begin{array}{c}\text { Females } \\
\text { Readmission }\end{array} \\
\mathrm{N}=39 \\
\%\end{array}$ \\
\hline Independent home & 44 & 75 & 41 & 67 \\
\hline Nursing home & 0 & 12.5 & 1 & 0 \\
\hline Parental home & 30 & 0 & 18 & 8 \\
\hline Group home & 0 & 0 & 12 & 5 \\
\hline Other situation & 19 & 0 & 25 & 15 \\
\hline Unknown & 7 & 12.5 & 3 & 5 \\
\hline
\end{tabular}


Table VI further explores the living situations of individuals by looking at these categories in relation to first admission requests and readmission requests. A difference in living situation is evident after a person has had psychiatric hospitalization. Fewer formerly hospitallzed persons lived in independent homes--3 per cent fewer males and 8 per cent fewer females. The data also shows a smaller percentage of readmission males living in parental homes. Thirty per cent seeking a first admission lived with parents as compared to 18 per cent seeking readmission. An opposite trend in the female population showed 0 per cent living with parents at the time of first request and 8 per cent of the readmission requesters living with parents. Thirteen per cent of the population lived in group homes, all of whom had been previously hospitalized. An increase is evident in the group of those living in "other living situation" after discharge--6 per cent more males and 15 per cent more females.

A general change in living situations for individuals after discharge from psychiatric hospitalization was evident. First admission men lived primarily in independent homes and parental homes, while more readmission men lived in group homes and other living situations. First admission women lived primarily in independent homes and 
readmission women lived more in parental homes, group homes and other living situations.

\section{B. Where Did They Come From}

Where the study population comes from is shown in Table VII. Counties of the Oregon State Hospital catchment area are ranked according to frequency of requests from those counties. Population density of the counties and the average number of miles from Oregon State Hospital are also demonstrated.

Seventy-five per cent of the population came from an average distance of seventy-five miles or less. Marion County, in which Oregon State Hospital is located, had the highest percentage of applicants- -40 per cent. A surprising 8 per cent of the people came from Jackson and Josephine Counties which are the furthest away from the hospital, while only 3 per cent came from Benton County, only thirtysix miles away. There seems to be no pattern in the study population with relationship to densities of the counties. Of those persons refused admission, 72 per cent lived in Marion County with the remainder from scattered distances within the catchment area. Not included were six individuals who were from outside the oregon State Hospital catchment area and two who were classified as transient. 
The studies of Rosenblatt (1974), Braginsky (1969, 1971) among others, also show that the pattern of greatest hospital use is made by individuals who live in closest proximity to it. 
TABLE VII

COUNTY OF RESIDENCY BY AVERAGE MILES FROM OREGON STATE HOSPITAL, DENSITY, FREQUENCY AND PER CENT

\begin{tabular}{|c|c|c|c|c|}
\hline County & $\begin{array}{c}\text { Average Miles } \\
\text { From OSU }\end{array}$ & Density & Frequency & $\%$ \\
\hline Marion & 29 & 129.8 & 72 & 40 \\
\hline Lane & 75 & 46.9 & 24 & 13 \\
\hline Linn & 46 & 31.5 & 16 & 9 \\
\hline Yamh111 & 29 & 56.6 & 8 & 4 \\
\hline Jackson & 174 & 33.6 & 7 & 4 \\
\hline Polk & 22 & 48.0 & 6 & 3 \\
\hline Clatsop & 82 & 35.4 & 6 & 3 \\
\hline Josephine & 174 & 22.0 & 6 & 3 \\
\hline Lincoln & 51 & 26.1 & 5 & 3 \\
\hline Benton & 36 & 80.5 & 3 & 2 \\
\hline Douglas & 116 & 14.2 & 3 & 2 \\
\hline Deschutes & 123 & 10.0 & 2 & 1 \\
\hline Tillamook & 58 & 16.1 & 2 & 1 \\
\hline Crook & 140 & 3.4 & 2 & 1 \\
\hline Klamath & 164 & .8 .4 & 2 & 1 \\
\hline Coos & 132 & 35.2 & 1 & 1 \\
\hline
\end{tabular}


C. How Did They Come

The second aspect of the study looks to how this population came to the hospital, where they came from and when they came.

TABLE VIII

TRANSPORTATION ASSISTANCE FOR VOLUNTARY

ADMISSIONS TO OREGON STATE HOSPITAL

\begin{tabular}{|c|c|c|c|}
\hline & $\begin{array}{c}\text { Males } \\
\mathrm{N}=129 \\
\%\end{array}$ & $\begin{array}{l}\text { Females } \\
\frac{N=49}{\%}\end{array}$ & $\begin{array}{l}\text { Total } \\
N=178 \\
\%\end{array}$ \\
\hline Relative & 22 & 25 & 22 \\
\hline Friend & 5 & 23 & 10 \\
\hline Police & 16 & 0 & 12 \\
\hline Other & 9 & 15 & 11 \\
\hline No one & 33 & 19 & 29 \\
\hline Unknown & 16 & 19 & 16 \\
\hline
\end{tabular}

How they came to the hospital is shown in Table VIII. The highest percentage of males, 23 per cent, came to the hospital seeking admission by themselves. The next most frequent means of transportation to the hospital was by relatives at 22 per cent, and the third most common means was by police at 16 per cent. Most females came to the hospital with the assistance of relatives and friends. 
25 per cent and 23 per cent respectively. The high percentage of females who came to the hospital with the assistance of friends can be compared to only 5 per cent of the males who came to the hospital in this way.

A look at the 16 per cent, or twenty-one men, brought to the hospital by police raises questions as to how voluntary these requests for admission were. Szasz (1972, p. 278) makes the point that voluntary mental hospitalizations can be unacknowledged fraud, if indeed there is coercion involved in their coming. It is known that in some specific cases, a landlord or some other concerned individual called police requesting transportation for the applicant. In other cases the individuals were given a cholce by the police or judge of voluntarily admitting themselves or going to jail.

Temporal Factors. The day of the week that the request was made and the time of day were two variables studied. Table IX reveals no significant clustering to indicate people coming to the hospital on one day of the week compared with others. Table $X$ shows that the majority of applicants requested admission between the hours of $4: 30 \mathrm{p} . \mathrm{m}$. and $12: 30$ a.m. at a rate of 49 per cent of the men and 56 per cent of the women. Thirty-eight per cent came during the day from 8:00 a.m. to 4:30 p.m.; expectedly few came between $12: 30$ a.m. and 8:30 a.m.--9 per cent. 
TABLE IX

DAY OF THE WEEK REQUESTS FOR

ADMISSION WERE MADE

\begin{tabular}{lccc}
\hline & $\begin{array}{c}\text { Males } \\
\frac{N=129}{\%}\end{array}$ & $\frac{N=49}{\%}$ & $\frac{N=178}{\%}$ \\
\hline Monday & 11 & 12 & 12 \\
Tuesday & 14 & 20 & 16 \\
Wednesday & 18 & 14 & 17 \\
Thursday & 16 & 8 & 14 \\
Friday & 16 & 17 & 16 \\
Saturday & 15 & 8 & 13 \\
Sunday & 8 & 19 & 11 \\
Holiday & 2 & 0 & 1 \\
\hline \hline
\end{tabular}


TABLE X

TIME OF DAY REQUEST FOR

ADMISSION WAS MADE

\begin{tabular}{|c|c|c|c|c|}
\hline & & $\begin{array}{l}\text { Males } \\
\frac{N=129}{\%}\end{array}$ & $\begin{array}{l}\text { Females } \\
\frac{N=49}{\%}\end{array}$ & $\begin{array}{c}\text { Total } \\
\mathrm{N}=178 \\
\%\end{array}$ \\
\hline $\begin{array}{l}3: 00 \text { a.m. - } \\
\text { 4:30 p.m. . . }\end{array}$ & · & 39 & 33 & 38 \\
\hline $\begin{array}{l}4: 30 \mathrm{p} . \mathrm{m} . \\
12: 30 \mathrm{a} \cdot \mathrm{m} .\end{array}$ & - & 49 & 56 & 51 \\
\hline $\begin{array}{l}\text { 12:30 a.m. - } \\
\text { 8:00 a.m. . }\end{array}$ & - & 9 & 8 & 9 \\
\hline Unknown . . & - & 1 & 1 & 2 \\
\hline
\end{tabular}

D. Why Did They Come

To consider why an individual would request admission to the Oregon State Hospital, we asked, "Did a particular situation or incident precipitate the admission request? If so, describe." The responses were grouped into categories based on common characteristics agreed upon by these investigators and reviewed by the Director of Social Services. Categories that contained at least 4 per cent or more of the population were selected for review and analysis. These were: onset of a symptom, social and environmental stress, alcohol, physically or verbally abusive, 
unable to provide for own needs, suicidal, and coerced voluntary admission. Table XI presents these categories in relationship to sex and admission request. 
TABLE XI

PRECIPITATING INCIDENT OF MEN AND WOMEN,

FIRST ADMISSION AND READMISSION,

OF THOSE SEEKING VOLUNTARY

ADMISSION

\begin{tabular}{|c|c|c|c|c|c|}
\hline & $\frac{\text { Total }}{\mathrm{N}=170}$ & $\frac{\text { Females }}{\mathrm{N}=48}$ & $\frac{\text { Males }}{N=122}$ & $\begin{array}{c}\text { First } \\
\frac{\text { Admission }}{N=} 35\end{array}$ & $\frac{\text { Readmission }}{\mathrm{N}=135}$ \\
\hline Onset of a symptom. & 19 & 29 & 16 & 28 & 18 \\
\hline $\begin{array}{l}\text { Soclal and environ- } \\
\text { mental stress . } .\end{array}$ & 20 & 33 & 16 & 25 & 18 \\
\hline Alcohol . . . . & 20 & 4 & 28 & 17 & 20 \\
\hline $\begin{array}{l}\text { Physically or ver- } \\
\text { bally abusive... }\end{array}$ & 8 & 6 & 10 & 19 & 7 \\
\hline $\begin{array}{l}\text { Unable to provide } \\
\text { for own needs... }\end{array}$ & 8 & 6 & 10 & 6 & 9 \\
\hline Sulcidal . . . . & 8 & 8 & 5 & 6 & 8 \\
\hline $\begin{array}{l}\text { Coerced voluntary } \\
\text { admission } \cdot . \cdot \text {. }\end{array}$ & 4 & 2 & 5 & 20 & 6 \\
\hline
\end{tabular}


"Social and environmental stress": this category was defined for the purposes of this study to include such precipitating incidents as severe employment, financial, marital and relationship difficulties; a death in the fam11y; fear of being physically abused by a spouse; and one incident in which a man reported that his wife left him and took the welfare check. Out of the total population, 20 per cent fell into this category. Of those, 25 per cent were first admission individuals and 18 per cent had previous admissions. Noteworthy, over twice as many women as men were overwhelmed by environmental or social stress, 33 per cent as compared to 16 per cent. When the sample was divided into age categories, no grouping was found for the women; however, for the men, 68 per cent fell within the age category of twenty to thirty-five which includes 48 per cent of the sample population.

One of the largest categories was that of "alcohol." Those included within this group related that they had gone on some type of extended "drinking bout" prior to their request for admission. From the total population, 20 per cent listed this as a precipitating factor, 17 per cent of those requesting first admission and 20 per cent requesting readmission. Alcoholic episodes divided by sex revealed 28 per cent were men and 4 per cent were women. Divided into age categories, the largest concentration of men appeared in 
the forty-one to fifty year old group. Fifty per cent of all men in this age group came to the hospital with alcohol as a precipitating factor, as did 37 per cent of the thirtyone to thirty-five year olds. Two women described alcohol as a precipitating factor, both between the ages of thirtysix and forty.

Another substance abuse category was drug abuse which was listed as a precipitating incident by 3 per cent of the total population. All of these were men and all except one was within the age range of twenty to thirty-five.

The third largest category was a category defined as "Onset of a symptom." Included within this category were paranola, confusion, withdrawal, bizarre behavior, hallucinations, depression, agitation, fear of becoming violent, and inability to sleep. Out of the total population, 19 per cent listed "the onset of a symptom" as the precipitating incident; 28 per cent were first admission requests, 18 per cent readmission. Twice as many women as men seemed to be suffering from the onset of a symptom--29 per cent as compared to 16 per cent.

A category was designed for those who were physically or verbally abusive. It included physical abusiveness towards family, destroying property, combative, and verbally abusive. This category contained 8 per cent of the total population; 19 per cent were those seeking first admission 
and 7 per cent were seeking readmission. Ten per cent of the male population were included in this category as were 6 per cent of the women. Seventy-five per cent of those who were physically or verbally abusive were men under the age of thirty. Two out of the three women were twenty-one to twenty-five.

A suicide attempt was a precipitating incident for 8 per cent of the population, 6 per cent of those seeking first admission and 8 per cent seeking readmission. Five per cent of the men were involved in a suicide attempt, as were 8 per cent of the women. The majority of those men attempting suicide were between the ages of twenty-one and twenty-five. No particular age category was noteworthy for the women.

"Unable to provide for their own needs" was a category including those who reported no place to stay, those who couldn't make 1t, and those who quit taking their medication. This was the precipitating incident for 8 per cent of the population; 9 per cent were those with multiple hospitalizations and 6 per cent first admission candidates. A slight sex difference is noted from the data: 10 per cent of the men were unable to care for themselves as were 6 per cent of the women. Elghty-three per cent of these men were under the age of thirty-five. No age grouping was seen for women. 
A category which contained 4 per cent of the total population was defined for the purposes of this study as "coerced voluntary admission." Included.were those who were usually brought to the hospital by law enforcement officers and to whom it had been e1ther suggested, recommended or made mandatory by the police or the court that this person seek voluntary admission. Of this group, all but one were men, 20 per cent were first admission and 6 per cent were multiple admissions. There was no relationship between age and this group.

From the literature one finds that in studying one hundred readmissions in a New York state hospital, Talbott (1974) found that only sixteen needed to be readmitted because of severity and progression of their symptoms: deterioration, regression, homicidal, suicidal and psychosocial. The presenting problems of the remaining eighty-four included situational stress, isolation, crisis, and medical problems. Smith (1963) wrote of the "decisive incident" resulting in a request for hospitalization in one hundred schizophrenic patients. These incidents almost always revolved around arousal of strong feelings of fear, shame, or disgust in the family or community.

Referral Source. In further examining why an individual would come to the Oregon State Hospital, this study asked "Who was the patient referred by?" The results of 
this inquiry indicated that women seem to be seeking community support prior to hospitalization far more frequently than the men. Thirty-eight per cent of the women first admission applicants were referred by clinics and physicians, compared to 15 per cent of the men referred by these same sources. Of those individuals seeking readmission, the same sex ratio seemed to hold. Fewer readmission applications were referred: 11 per cent fewer women and 3 per cent fewer men.

"Other" was one possible response to the question regarding referral source; when "other" was indicated, the questionnaire asked the respondent to specify. By far the two most common responses were police and friends. A high percentage of the first admission men were referred by "other"; 41 per cent compared to 13 per cent of the women. An examination of those individuals seeking readmission revealed that 23 per cent of the readmitted men indicated "other" as a referral source which was considerably fewer than first admission men. A completely opposite trend was seen in the women, well over twice as many readmission women--31 per cent compared to 13 per cent--indicated "other" as a referral source.

Finally, it is noteworthy that 37 per cent of the first admission men and 44 per cent of the readmission men were referred by no one. Significantly fewer women were 
referred by "no one"; 25 per cent at first admission and 23 per cent at readmission, once again underlining the notion that the men seemed to come without prior benefit of a community resource much more often than did women. Table XII demonstrates these relationships.

In analyzing these referral sources, the population was broken into age categories. Analysis of this variable indicated that there seemed to be no relationship between age and the referral source. 
TABLE XII

REFERRAL SOURCE OF FIRST ADMISSION

AND READMISSION OF MEN AND

WOMEN REQUESTING

ADMISSION

\begin{tabular}{|c|c|c|c|c|}
\hline & \begin{tabular}{c}
\multicolumn{2}{c}{ Males } \\
First Admission \\
$\mathrm{N}=27$ \\
$\overline{\%}$
\end{tabular} & $\begin{array}{c}\text { Females } \\
\text { First Admission } \\
\mathrm{N}=8 \\
\%\end{array}$ & $\begin{array}{c}\text { Males } \\
\frac{\text { Readmission }}{N=95}\end{array}$ & $\begin{array}{c}\begin{array}{c}\text { Females } \\
\text { Readmission }\end{array} \\
\begin{array}{c}\mathrm{N}=40 \\
\%\end{array}\end{array}$ \\
\hline Clinic & 4 & 13 & 7 & 3 \\
\hline Physician & 11 & 25 & 5 & 11 \\
\hline Agency & 0 & 0 & 0 & 13 \\
\hline Other & 41 & 13 & 23 & 31 \\
\hline No one & 37 & 25 & 44 & 23 \\
\hline Unknown & 4 & 25 & 14 & 21 \\
\hline
\end{tabular}


Community Involvement. In an effort to consider further the use of community resources we asked, "Had the patient been in contact with any community service or mental health agency Just prior to request?" The majority, 53 per cent of all patients requesting admission, had had no community resource contact prior to admission. Further analysis indicates that 26 per cent of the men and 50 per cent of the women requesting first admission were in contact with community resources. Once again the se figures indicate that women seem to use community resources prior to admission at a much greater frequency than do men. Finally, in the breaking down of the contact with community resources into age categories, there was no relationship between age and the use of community resources. Table XIII demonstrates these relationships. 
TABLE XIII

CONTACT WITH COMMUNITY RESOURCES PRIOR TO REQUEST FOR ADMISSION

\begin{tabular}{|c|c|c|c|c|}
\hline & $\begin{array}{c}\text { Males } \\
\frac{\text { First Adm1ssion }}{\mathrm{N}=27} \\
\frac{\bar{\phi}}{27}\end{array}$ & $\begin{array}{c}\text { Females } \\
\frac{\text { First Admission }}{\mathrm{N}=8} \\
\bar{\phi}\end{array}$ & $\frac{\begin{array}{c}\text { Males } \\
\text { Readm1ssion }\end{array}}{\mathrm{N}=95}$ & $\frac{\begin{array}{c}\text { Females } \\
\text { Readmiss 1on }\end{array}}{\mathrm{N}=39}$ \\
\hline Yes & 26 & 50 & 26 & 38 \\
\hline No & 63 & 50 & 61 & 51 \\
\hline Unknown & 7 & 0 & 12 & 10 \\
\hline
\end{tabular}


Treatment Other Than Hospitalization. Table XIV

takes a final look at the use of community resources and asks whether an individual has recelved any type of treatment prior to hospitalization, and if so, what kind. In considering these figures, there is a high percentage of unknowns in both the male and female categories; therefore, only tendencies can appropriately be considered. The responses, however, indicate that more than twice as many men as women were not recelving any type of treatment prior to their first hospitalization--18 per cent compared to 6 per cent respectively. Further, proportionately many more women than men were receiving treatment from physicians prior to their first hospitalization. However, for the women this dropped drastically on readmission from 50 per cent having seen a physician to 21 per cent. Clinic treatment, however, was greater for readmission men and women. The responses to this question seem to reflect a general trend towards more community treatment. After the first hospitalization, there was a 9 per cent drop in the men recelving no treatment, and for women an 8 per cent decrease. A review of literature found Decker (1974) and Franklin (1975) both reporting that mental patients returning to the hospital usually had had more contact with community mental health resources than those former patients who did not return to the hospital. 
TABLE XIV

TREATMENT OTHER THAN HOSPITALIZATION

\begin{tabular}{|c|c|c|c|c|}
\hline & $\begin{array}{c}\text { Males } \\
\text { First Admission } \\
\mathrm{N}=27 \\
\%\end{array}$ & $\begin{array}{c}\text { Females } \\
\frac{\text { First Admission }}{N=8} \\
\% \%\end{array}$ & $\begin{array}{c}\text { Males } \\
\frac{\text { Readmission }}{\mathrm{N}=9 \overline{5}} \\
\% \%\end{array}$ & $\frac{\begin{array}{c}\text { Females } \\
\text { Readmission }\end{array}}{\mathrm{N} \overline{\bar{\phi}}}$ \\
\hline None & 26 & 13 & 17 & 5 \\
\hline Physician & 15 & 50 & 14 & 21 \\
\hline Clinic & 22 & 25 & 27 & 33 \\
\hline Other & 11 & 0 & 9 & 8 \\
\hline Unknown & 26 & 13 & 31 & 31 \\
\hline
\end{tabular}


Previous Hospitalization. The study sought to examine those individuals who had previously been hospitalized. It inquired as to the number of previous psychiatric hospital1zations as well as the date of the last hospitalization. Refer to Table XV, page 61 and Table XVI, page 62 .

An examination of the data revealed little difference between men and women in the number of previous hospltalizations. However, out of those who had been hospitalized there was a large group with multiple hospitalizations. For example, of those who had multiple hospitalizations, 59 per cent of the women had more than five hospitalizations and 41 per cent of the men had more than five prior hospitalizations.

An analysis of the data of the last hospitalization indicated that the majority of both men and women with previous hospitalizations had been in a psychiatric fäcllity less than one year ago. For men, 69 per cent had been hospitalized less than one year ago; for women, 58 per cent. Although there seemed to be little difference by sex in those who had been rehospitalized within a year, there was a substantial difference by sex among those individuals who had been in a hospital within the previous two weeks. One finds here that among the men who had been rehospitalized within one year, 41 per cent found 1t necessary to return to the hospital within two weeks. The women did not return as 
frequently. Of the 58 per cent women who were rehospital1zed within one year, 17 per cent found 1t necessary to return to the hospital within two weeks, still a high proportion. It must be noted that the Oregon State Hospital has the practice of giving full discharge to voluntary patients who do not return as scheduled from hospital leave. This may account for some of those who returned within such a short time.

Finally, out of the 178 requests for admission to the Oregon State Hospital, only thirty-five persons, or 20 per cent, had never been hospitalized. Thus, 76 per cent of our entire sample had been in a psychiatric facility; of those, 64 per cent less than one year ago and of those, 31 per cent within the last two weeks. Of all those individuals who had been previously hospitalized, 53 per cent had had more than five hospitalizations.

The high rate of recidivism in mental patients is the subject of many studies: Buell (1973), Discipio (1973), Eaton (1974), Flomenhaft (1969), Franklin (1975), Lorie (1973), and Weinstein (1973). However, none of these studies reported rates of recidivism as high or as soon after hospital release as does our study. 
TABLE XV

DATE OF LAST HOSPITALIZATION

\begin{tabular}{|c|c|c|}
\hline & $\frac{\text { Males }}{\frac{\mathrm{N}}{\bar{\phi}^{1}}}$ & $\frac{\text { Females }}{\frac{\bar{y}}{\%}}$ \\
\hline None & 20 & 17 \\
\hline Less than 2 weeks & 41 & 17 \\
\hline 2 weeks to 2 months & 9 & 10 \\
\hline 4 months to 6 months & 9 & 16 \\
\hline 7 months to 1 year & 10 & 15 \\
\hline 1 to 2 years & 11 & 6 \\
\hline . 2 to 3 years & 3 & 0 \\
\hline 3 to 4 years & 2 & 0 \\
\hline 5 to 10 years & 0 & 10 \\
\hline 10 to 20 years & 1 & 6 \\
\hline $21+$ years & 0 & 2 \\
\hline Unknown & 17 & 10 \\
\hline
\end{tabular}


TABLE XVI

NUMBER OF PREVIOUS HOSPITALIZATIONS

\begin{tabular}{lccc}
\hline & Males & $\begin{array}{c}\text { Females } \\
\bar{N}=127\end{array}$ & $\begin{array}{c}\text { Wopulation } \\
\text { Pot } \\
\text { None }\end{array}$ \\
\hline None & 20 & 17 & 19 \\
1 & 17 & 18 & 13 \\
2 & 14 & 18 & 12 \\
3 & 13 & 5 & 8 \\
4 & 5 & 3 & 3 \\
5 & 4 & 13 & 5 \\
$6-10$ & 16 & 10 & 11 \\
$11-20$ & 9 & 0 & 5 \\
$21+$ & 5 & 3 & 3 \\
Unknown & 18 & 31 & 17 \\
\hline \hline
\end{tabular}


Admitting Physician. Twenty-one physiclans processed requests during the fifty-nine days of the study. It was noted that the physicians assigned to the ward of the hospital's home county, Marion, admitted the largest number of patients, 72 or 40 per cent of the sample. This is in keeping with the fact that Marion County has the largest number of residents in the hospital. No pattern was revealed in the admitting or denying practices of individual physicians.

A high percentage, 64 per cent, of the physicians indicated that they did not know the requester. This is interesting to note since 34 per cent of the sample had been in the hospital less than two weeks before, and 64 per cent had been in within a year's time.

E. Hospital Response

Collateral Contacts. After considering who comes, from where, and why, we further sought to consider what happened to those individuals requesting admission. Following this line of inquiry, we asked, "Were any collateral contacts made (e.g., clinic, detox). The data reveals that when an individual presents himself for admission, few contacts with the community are made, and those that are made are made predominantly for men.

Table XVII demonstrates that for 13 per cent of the men requesting admission, there was a collateral contact made. 
TABLE XVII

COLLATERAL CONTACTS AND RESULT

OF ADMISSION REQUEST

\begin{tabular}{|c|c|c|c|c|}
\hline & $\begin{array}{c}\text { Males } \\
\text { First Adm1ssion } \\
\mathrm{N}=27 \\
\not \mathscr{0}\end{array}$ & $\begin{array}{c}\text { Males } \\
\frac{\text { Readm1ssion }}{\mathrm{N}=95} \\
\% \%\end{array}$ & $\begin{array}{c}\text { Females } \\
\frac{\text { First Adm1ssion }}{N}=8 \\
\phi \phi\end{array}$ & $\begin{array}{c}\begin{array}{c}\text { Females } \\
\text { Readmission }\end{array} \\
\mathrm{N}=40\end{array}$ \\
\hline $\begin{array}{l}\text { Collateral } \\
\text { contact... }\end{array}$ & 11 & 12 & 0 & 8 \\
\hline $\begin{array}{l}\text { No collateral } \\
\text { contact. }\end{array}$ & 77 & 83 & 88 & 82 \\
\hline No response . & 11 & 5 & 12 & 13 \\
\hline Admitted . . & 81 & 84 & 100 & 92 \\
\hline Refused . . & 7 & 6 & 0 & 7 \\
\hline $\begin{array}{l}\text { Refused and } \\
\text { referred }\end{array}$ & 11 & 8 & 0 & 0 \\
\hline $\begin{array}{l}\text { Patient } \\
\text { refused... }\end{array}$ & 0 & 0 & 0 & 1 \\
\hline
\end{tabular}


Most of these contacts for the men were with the alcoholic detoxification center. Of first admission men, ll per cent had collateral contacts. Twelve per cent of the readmission men had collateral contacts, and 8 per cent of the readmission women had contacts made for them. When collateral contacts were divided into age categories, there seemed to be no noticeable grouping for the men. However, for the women, out of the four collateral contacts made, three of them were made for women in the age category of sixty-one to seventy.

Request Outcome. What was the outcome of their requests? The study found four categories useful in analyzing the dispositions of requests for admissions: admitted, refused, refused and referred, and patient refused. The overwhelming majority of both men and women were admitted. One hundred per cent of the first admission women were admitted, 92 per cent of readmission applicants were admitted and 7 per cent were refused admission. Three women made up the 7 per cent refused, one woman was out of the catchment area, the other two had just recently been in the hospital and were presenting situational difficulties which apparently were not considered severe enough by the admitting physician to warrent admission. There were no women refused and referred. One woman refused to enter the hospital after going through the admission process. 
Turning to the men, 81 per cent of the first admission men were admitted. Out of the remaining 19 per cent, 7 per cent, or nine men, were refused and referred. Of those, elght were alcoholics referred to White Oaks, the Marion County Detoxification Center, or a public hospital, and one was referred to a county mental health clinic. Of seventeen men refused admission, eleven were individuals who had been in many times. They were considered chronic by the admitting physicians and were presenting situational difficulties not severe enough to warrent admission. Four men were out of the catchment area and two were brought in by the police but when questioned, did not want admission. Elghty-four per cent of the men who were applying for readmission were admitted, a higher percentage than first admission.

In considering the collateral contacts and the admission outcome, it appears that when an individual presents himself for admission to Oregon State Hospital, there is little contact with the community as to whether the admission is appropriate. Ninety-two per cent of those admitted had no collateral contacts made on their behalf, 27 per cent of those individuals refused or refused and referred had no collateral made for them. The individual seeking admission is admitted almost without exception, especially if that person is a woman. 
Literature review in this area reveals a study by Mendel, Werner and Rapport (1969). They found that the decision makers in the hospitalization process rarely chose to exercise their influence in keeping individuals out of the hospital. On the basis of their study, Zwerling and Karauit (1975) believed that it was easier for admitting staff to fill out a form and send the requester along to a ward than to sit and talk to him about his problem.

\section{F. Diagnosis}

We turn now to examine the diagnosis of the individual who has presented himself or herself for admission to the Oregon State Hospital. For the purpose of this inquiry, a wide range of diagnostic categories was developed to describe the presenting problem. The diagnostic categories which contained at least 5 per cent of the population were selected for further study. Table XVIII demonstrates these relationships. 
TABLE XVIII

DIAGNOSIS OF THOSE REQUESTING ADMISSION, MALES AND FEMALES, FIRST AND

READMISSION

\begin{tabular}{|c|c|c|c|c|c|c|c|}
\hline & & & $\frac{\text { Total }}{\mathrm{N}=170}$ & $\frac{\text { Females }}{\mathrm{N}=48}$ & $\frac{\text { Males }}{\mathrm{N}=122}$ & $\frac{\text { First Admission }}{N=35}$ & $\frac{\text { Readmission }}{\mathrm{N} \bar{\not}_{0} 135}$ \\
\hline Alcohol . . & • & - & 26 & 14 & 31 & 19 & 27 \\
\hline Psychosis. & - & - & 23 & 31 & 20 & 14 & 25 \\
\hline $\begin{array}{l}\text { Affective } \\
\text { disorder. }\end{array}$ & - & • & 19 & 38 & 11 & 31 & 18 \\
\hline $\begin{array}{l}\text { Personal1ty } \\
\text { disorder . . }\end{array}$ & • & • & 9 & 2 & 11 & 11 & 8 \\
\hline Sulclde . . & • & • & 6 & 6 & 6 & 11 & 5 \\
\hline $\begin{array}{l}\text { Physical } \\
\text { problems... }\end{array}$ & $\cdot$ & • & 6 & 2 & 7 & 0 & 100 \\
\hline $\begin{array}{l}\text { Situational } \\
\text { difficulties }\end{array}$ & & • & 5 & 4 & 5 & 0 & 100 \\
\hline No response . & . & $\cdot$ & 6 & 3 & 7 & - $\cdot$ & - . \\
\hline
\end{tabular}


The most frequent diagnostic category was that of alcoholism. Of the total population, 26 per cent were assigned this diagnosis. Significantly, over twice as many males as females were diagnosed as alcoholic, 31 per cent of the males as compared to 14 per cent of the females. A look at alcoholism with regard to age demonstrated an even distribution of female alcoholics in all age groupings. Of the males diagnosed as alcoholic, 68 per cent were forty years or older, and 38 per cent were forty to fifty years old.

Another form of substance abuse 1dentified by this study as a diagnostic category is drug abuse. Of the total population, 9 per cent fell into this category. Eleven per cent were persons requesting their first admission, 8 per cent readmission. When divided into men and women, 6 per cent of the women were drug abusers as were 9 per cent of the men. While there seems to be little difference between men and women, there was a significant difference when considering age. We found that of the 6 per cent women diagnosed as drug dependent, all were between the ages of twenty-one and thirty-five. For the men the same distribution seems to hold, although the figures are not as starting; 83 per cent of the men are below the age of thirty-five.

In reviewing the two substance abuse categories, alcohol and drugs, we observe 35 per cent of the total 
population included in these categories, 49 per cent of them men and 23 per cent women.

The Diagnostic and Statistical Manual: Mental Disorders (1964) defines psychosis as:

. . disorders . . characterized by a varying degree of personality disintegration and fallure to test and evaluate correctly external reality in various spheres. In addition, individuals with such disorders fall in their ability to relate themselves effectively to other people or to their work.

Out of the total population, 23 per cent were diagnosed as psychotic; 14 per cent were individuals seeking first admission, 25 per cent readmission. Of the women, 31 per cent were given this diagnosis as were 20 per cent of the men. Although the division between men and women was not statistically significant, there was a significant relationship at the .05 level between age categories and the diagnosis. Sixty-eight per cent of the men fell in the age group of twenty to thirty-five. The relationship was not significant for the women, however; 60 per cent fell within the age grouping of twenty to thirty-five.

A diagnostic category of "affective disorder" as defined for the purposes of this study, includes those described as depressed, agitated, hypermanic, and manic. of the total population, 19 per cent were diagnosed as having affective disorder; of those, 31 per cent were individuals requesting their first admission, 8 per cent readmission. 
An interesting sex difference is noted. Over three times as many women had this diagnosis, 38 per cent as compared to the men's 12 per cent. Subdivided into age groupings, no significant relationship was demonstrated among age categories. For the men, 67 per cent fell within the age range of twenty to thirty-five, 40 per cent of the population. The diagnosis was scattered evenly for the women. The diagnostic category of "personality disorder" is defined by The Diagnostic and Statistical Manual: Mental Disorders as:

or pathological trends in the personality struc-
ture, with minimal subjective anxiety, and little
or no sense of distress. In most instances the
disorder is manifested by a lifelong pattern of
action or behavior, rather than by mental or emo-
tional symptoms.

Nine per cent of the total population applying, for admission to Oregon State Hospital was diagnosed as having a personality disorder. Of those, 11 per cent were applying for first admission, 8 per cent readmission. Out of the entire male population, 11 per cent were diagnosed as having a personality disorder. Interestingly, only 2 per cent of the women were labeled as such. One-half, or 50 per cent, of them fell in the age category of twenty-one to twentyfive. The rest were scattered evenly among the other age categories. 
A suicidal attempt was listed by the admitting physiclan as a diagnosis in 6 per cent of the total population. Individuals seeking their first admission composed 11 per cent of the total, and 5 per cent were readmissions. There was no sex difference; of those diagnosed as sulcidal, 6 per cent were men and 6 per cent were woman.

Another diagnostic category that was defined, and contained 6 per cent of the total population, was "physical problems." This category included problems with selzures, hypertension, medication adjustment, and psychosomatic a11ments. One hundred per cent were individuals seeking readmission. Seven per cent of those diagnosed as having physical problems were men, whereas 2 per cent were women.

One final category was "situational difficulties." Incluaed in this category were those who were unable to care for themselves, who presented too much of a problem to the community, who were having extreme family or marital difficulties and who had problems with living arrangements or employment. Out of the total population, 5 per cent were included in this category. Interestingly, all were individuals seeking readmission. The diagnosis of "sitliational difficulties" was given to 5 per cent men and 4 per cent women.

A number of studies--Braginsky (1969, 1973), Buell (1973), DiScip1o (1973), Flomenhaft (1969), Franklin (1975), 
Miller (1966), Mendel (1969), Maxmen (1973), Rosenblatt (1974), Smith (1963), and Talbott (1974)--made the point that admission to mental hospitals usually had much more to do with a cluster of situational factors than with symptoms or their severity.

A $T$ test was computed and 1 t was found that there were no significant differences between first and readmission groups with respect to any of the diagnostic categories. 


\section{CHAPTER V}

\section{SUMMARY OF DATA}

\section{A. Characteristics of the Population}

The purpose of this study was to produce a picture of the individual presenting himself to Oregon State Hospital for voluntary admission. Data was examined and has been presented in such a way as to describe who comes to Oregon State Hospital requesting voluntary admissions, how they come, where they come from, why they come, hospitalization history and hospital response to their request. Further analysis for understanding the requesting population was made of the differences between those admitted and those refused admission; between those requesting first admission and those seeking readmission; between age groupings and between males and females. To reiterate, the intent of the study was to gain knowledge of the characteristics of the self-requests for admission, therefore assisting in the development of services that will positively rather than adversely affect the requester's condition. The following is a summary of the study findings, characterizing the sample population:

During the fifty-nine day period of the study, 2.6 times as many men as women requested admission. More than 
75 per cent of these requesters had a history of hospitalization with approximately the same percentage claiming to be unemployed. Almost one-half the sample population lived in independent homes at the time of their request, with the next highest number living in parental homes.

The highest percentage of individuals came to the hospital by themselves; of this number the majority were men. The next highest number came to the hospital with the assistance of relatives, with the greatest percentage of females falling into this category. Other common means of transportation were assistance by friends for the women and assistance by the police for the men.

The vast majority of the study population resided a distance of seventy-five miles or less from the hospital.

More than half of them came between the hours of $4: 30$ p.m. and 12:30 a.m., showing no preference to one day of the week over another.

The study asked why an individual applied for admission. Findings showed that 60 per cent of those seeking admission fell into three categories which described the precipitating incident leading to their request. Twenty per cent were included in a category described as "Social or environmental stress." There were twice as many women as men. Another 20 per cent were involved in the abuse of "alcohol"; these were almost exclusively men who were forty 
and over. "Onset of a symptom" included the remaining 19 per cent; again there were twice as many women as men.

of the remaining categories dealing with the precipitating incident, only one ("suicidal attempt") had a higher proportion of women. Men under the age of thirty-five composed the largest percentage of those individuals in the categories of "physically and verbally abusive," "Inability to provide for their own needs," and "coerced voluntary admission."

The study learned that there was little community contact or treatment prior to admission request and those who were involved in community treatment were women. Specific responses indicated that those first admission women who were referred came from clinics and physicians substantially more often than men. Men, on the other hand, indicated that they were referred most frequently by "others," which included for the most part police and friends.

Investigation into the number and frequency of those who have been previously hospitalized revealed engaging results. Seventy-nine per cent of our entire sample had been in a psychiatric facility. Sixty-four had been hospitalized within one year, and a third of our sample had been in less than two weeks before; these individuals were mostly men over forty. The majority of the Oregon State Hospital population had had more than five hospitalizations. 
The outcome of the admission request was closely examined and revealed that when an individual sought admission this person would most likely be admitted with the exception of some alcoholics. Few collateral contacts were made in the behalf of those seeking admission. There were no distinguishing characteristics between those admitted and those refused admission.

Finally, investigation of diagnosis revealed that 77 per cent of those seeking admission fell into three categories, substance abuse, psychosis, and affective disorders. Alcohol was the largest category containing over twice as many men as women; most of these men were over forty. Abuse of drugs composed the remainder of the substance abuse category; these men and women were for the most part under thirty-five. Psychosis was the next largest category; slightly more women than men made up this group and the majority were under thirty-five. The third largest grouping was affective disorder which contained three times as many women as men of all ages.

Young men under twenty-five years made up the majority of the diagnostic group of personality disorder. This category involved 8 per cent of the total population. Sulcide and situational difficulties were small diagnostic categorles which revealed no sex or age grouping, and a final 
category consisting of 5 per cent of the total population was somatic complaints; these were mostly men.

B. Summary of Demographic Data

Difference Between Admitted and Refused Individuals.

A further analysis of the data led to examination of differences between those individuals admitted and those refused admission. The vast majority of those refused admissions resided in the county where the hospital is located, and had slightly more collateral contacts made on their behalf. of those refused and referred to community resources, most were labeled alcoholics. Persons who were refused admission and not referred to community resources were refused on the grounds that their situation was not severe enough to warrant admission or because they resided outside the hospital's catchment area. There were no other demographic differences between those admitted and those refused admission among the variables studied.

Difference of First and Readmission Population. In comparing those applying for admission for a first time with those having a history of hospitalization, there was evidence of increased dependency by those having been hospitalized previously. Unemployment was higher, more community dependent living arrangements were utilized, and increase in community treatment was characteristic of applicants for 
readmission. Misuse of alcohol and the inability to provide for their own needs were factors which brought this population back to the hospital. Diagnostically, they were labeled psychotic and alcoholic more frequently than those seeking first admission. The first admission population had precipitating incidents of "onset of a symptom" and "social and environmental stress." The two most common diagnostic categories for this population were affective disorder and sulcide.

Demography Differentiated by Age. Analysis of age groupings revealed that the majority of those in the study were younger, that is, thirty-five years of age or less. The employed male applicants fell into this younger age span, while the most common incidents preceding their request for admission were an inability to provide for their own needs, suicide attempts, and acts of physical abuse to themselves or others. The older male population, those over the age of thirty-five, had a more prevalent misuse of alcohol as a precipitating incident. Diagnostic categories for both males and females showed the younger population character1zed as drug abusers, personality disorders, psychotics, and having affective disorders. For the older population the diagnosis was mainly alcoholism.

Demography Differentiated by Sex. Finally, the differences between men and women were analyzed. A profile of 
the male population shows that men were in their twenties and early thirties, slightly younger than the women. They tended to live with their parents or in "other situations," and came to the hospital by themselves or with the assistance of relatives or the police. They came to the hospital most often because of episodes of alcohol abuse, physical and verbal abuse of others, suicide attempts and the inability to provide for their own needs. The most common diagnoses for the male population were alcoholism, personality disorder, and somatic problems. Men sought little community support or treatment. High percentages of males returned to the hospital within a two-week perlod after discharge. Most collateral contacts made by the admitting staff were for men.

A composite sketch of the female requesting admission revealed that the women came from an independent home where she or her spouse was the head of the household. The women used community resources and came to the hospital by referral. Nearly all of those making application were admitted. Social and environmental stress and onset of a symptom were the most frequent precipitants to females' request for admission. The highest diagnostic category was an affective disorder. 
CHAPTER VI

\section{VIGNETTES}

The statistical picture of the Oregon State Hospital voluntary admission requests and process does not adequately describe the human feelings and needs that are contained in the requests and process. The following examples attempt to 1llustrate the impact and complexity of the human aspect.

An experienced physician sat in the small examining room at 9:30 a.m. He was questioning a seventy year old male resident of Marion County. The physician had a chart in front of him.

Mr. Brown, I see you were in last October for alcoholism and left in November. What could we do for you this time that we haven't done before?

Doc, I'm really sick.

He had been walting since $7: 30$ that morning, was almost convulsive with tremors, perspiring heavily and very ashen.

I know, Mr. Brown, I feel badly about that, but perhaps you should go to White Oaks (the detox center). You're sick because you've been drinking.

Doc, they don't want me there. I've been there twice since Christmas and besides, I'm really sick. I was so weak I couldn't get out myself. Last night I had D.T.'s so bad and was so sick that when my nelghbor checked 
the noise, I asked him to call the police to come and get me. Doctor, I can't make 1t. I got to have help.

Mr. Brown, how can we know if we take you in and treat you that it will be any different?"

Doc, I'm really going to try--I'm really going to this time. I'm sick. I can't make it like this. It's going to kill me.

Mr. Brown was crumpled in his chair by this time and looked as though he could pass out at any minute. Dr. sighed and sald:

O.K., Bill, let's get you to the ward and see what we can do.

Marty, an a1de, spoke to one of us about a fortyseven year old man who had been in and out of the hospital twelve times in the last five years. The treatment program for substance abuse had refused to take him because of his lack of motivation and resistance to their treatment program.

Well, I just don't know. If they kick Fred out of the hospital, he'll get drunk and sick all over again. As hard as he works for this hospital without being asked, I don't think it's fair--what's a human life worth anyhow? He does fine in here and does terrible in group homes and stuff outside.

Turning quickly to a huge, babylsh looking man of about thirty-five: 
Oh, George, what am I going to do with you? You've ripped the buttons off your shirt again, and I try so hard to keep you looking nice.

The Social Services Director at Oregon State Hospital used an illustration to explain the rehospitalization pattern to us:

John is a ninety-five year old patient who has been in the hospital since 1932 and works every day at the motor pool garage. He is an example of someone who became institutionalized and could have made it on the outside. Staff who were fond of him, knowing that he had occasional upsets that might bring him back in, collaborated in his efforts to avold the move. Placement could have been made that would not interfere with his job. The new policy, which often seems like a revolving door in the way people go in and out, eventually works for a majority of patients, facilitating their function in situations, that keeps them out of the hospital.

Ingrid, a young a1de at Oregon State Hospital, also discussing John:

Have you met $\mathrm{Mr}$. wonderful man, like a grandfather to us.

We listened to a training tape of Frank Pittman, M.D., addressing a conference about his experiences in developing community care: 
I Eot to be called the fastest gun in the West; an injection of Stelizine [one of the psychotropic drugs], and I would tell someone to go home and clean the kitchen sink. Continuing role function is the thing; there is little we have to do in terms of function that can't be done while hallucinating.

At a ward meeting, the reorganization of the community wards was being discussed. Tom, a long-term schizophrenic patient, with a tortured face, stood:

I want to know, as the owner of this hospital, what do you intend to do with me?

Later in the same meeting he stood again to defend another patient whose whiny complaints were bringing laughter from patients:

Now, you don't understand George. He came here as a young man from that ranch and has been in that home and doesn't like it, and is back. This isn't a good place for him. He's right, he needs something different.

A housekeeper was showing us into the room we could use for overnights:

Yeah, the legislature was here last week to look things over. They know now after several years that communities don't want and can't keep these people. We're set 
up for it and so is the town. They're going to have to fix up some of these facilities and take a lot back in.

We spoke to a mother bringing her son to Oregon State Hospital with a letter of referral from the psychiatrist in her town some two hundred miles away. She was unemployed and a member of a minority group.

I thought they could take him into the part of the hospital for young people for treatment. I don't want to leave him here with all these people, he'll get more upset.

She did leave him. His stay was short, two weeks, and in a few days he was obviously feeling and functioning much better. He was returned to community care.

A member of the communications staff who helped us fill out the questionnaires:

You want to know if the people coming in have tried the community mental health clinic first? I can tell you that, sure, most of them have tried and get told that they'll have to walt six weeks or so for an appointment. 
In finishing an incomplete questionnaire, the question was asked:

Was there a difflculty or 1nc1dent that helped you decide to come in?

The spry, sixty-year-old woman answered:

Well, you see, I like to take showers and sing, sometimes at night. I knew it wouldn't work out there. The landlord called the police and he was a nice young man. He took me by my daughter's. He just didn't want to bring me here, but I told him, "I want to go back!" I hope they let me stay this time. I'm just so tired of moving. I like it here. There's lots to do. I like the people. I worked and paid my taxes; my kids pay their taxes. I don't want to live with them. I sure hope they let me stay this time.

Again, filling out a questionnaire: "Was there an incident that brought you back?"

This is my third time. The first time I was brought in (sex offense). This time I realized I shouldn't have left in October.

There was this girl I met here. We took our cannery money and went to Nevada. After a while she left and I got drunk and wrecked up my truck and had to do some time. When I got out, I started back. I've got friends here. I think 1t's the only place I've got friends.

Who are your friends?

Two aldes in securlty, I can always talk to them, Dr. T. and C. [a member of the substance abuse team]'. They're always here. 
In a conversation with the alcohol specialist in the Division of Mental Health, the researcher mentioned her interest in the number of multiple requests for admission during the study. One of the men who was in the hospital twice in the two months was also in White Oaks once during that time. The specialist asked: "What was his name?" I told her. "Good grief! I was at Lane County's detox center in March and he was in there then."

Thomas Szasz spoke in an address at oregon State Hospital the week of March 8, 1975:

. . The walls of hospitals need to be taken down . . . the only people who should have to stay in mental hospitals are the people who want to stay in them.

Gerald Klerman, a panel member, responded to his remarks :

Everyone knows that community service is best and have been moving towards it for years where people can be close to their families.

Szasz, again:

The only people that get sent to community mental health clinics are the ones that want to stay in the hospital, the ones that are locked up want out. 
A Master of Social Work student assigned to a community mental health clinic in another catchment area commented in a conversation with us:

The clinics are crowded; everyone, including students, are called "therapists." The largest number come because of their medication; first-year MSW students are expected to do medication evaluations. It's that way in all of them.

A ward clerk responded to one of the researchers asking about the man who had made six requests for admission during our study. He was kept out once.

No, that's not right, he's not a drinker or drug abuser. It's awfully sad. He's such a young man and is just awfully sick. He literally can't stand staying in the hospital. He comes in when he's lost his medicine or can't find where he lives. They've tried everything with him. He does better to be let alone and sometimes they find a landlord to help him out by sort of keeping track of his medicine. He just takes off from group homes, everywhere. They're going to try keeping him out for a while and see if he won't work through community mental health, maybe it $\eta 1$ work this time.

A middle-aged woman, mother of four, spoke with tired frustration: 
I don't understand this place. I've been here four days and only seen the doctor once and all that's happening for me is to get lots of medicine. I came in because I knew I needed help. I might as well be back home sitting in my truck looking at the river [where she had been spending all her days] as sitting in here.

A twenty year old farm boy who looked younger spoke similarly:

Nobody talks to me or tells me anything. I haven't seen a doctor since I came in (four days before). My folks brought me here 'cause they didn't know what else to do.

These notes were written on the questionna1re:

He has epllepsy, had worked for one man for fourteen years. His boss sold his business and the new owner fired him. He was getting more depressed, drinking.

His wife brought him in. He had been in once about fifteen years before.

I asked a young, tired looking woman: "Was there an incident that brought you in?"

My husband just went to prison; I have two kids at home, I don't know. This pregnancy and all. I'm just worn out. I felt like I had to get away. 
Less than seventy-two hours after admission, she asked to leave, was given permission, and left $1 \mathrm{~m}-$ mediately.

I'm too worried about my kids.

In another interview, to complete a questionnaire I asked the standard incident question of a beautiful young woman:

I don't want to talk about 1t. It's in. my chart.

I went and checked the chart. There was a letter from a judge asking that she be admitted. She had been in his court more than once on charges having to do with drugs, the last time having to do with shoplifting charges. Her cholce had been the hospital or jail.

On one questionnaire, in response to the question, "Was the patient referred by," "Other" was checked with a note:

A friend told him it was a good hospital. He was denied admission. 
Dr. $X$, the clerk's records say you turned down a man's request for admission two days ago. There wasn't a screening note; would you give us as much information as you can to complete our questionnaire?

Oh, yes, that was the man the police brought in. He had made a nuisance of himself in a downtown restaurant, waving an unloaded gun around and making threats. I frankly thought he was psychotic, but he didn't want to come in. The police had walted until their hold ran out and then brought him up here and wanted us to take him. He was a voluntary so I had no justification in bringing him in on an emergency hold. I don't know what they did after that.

Lonny, a large, overwelght man in the substance abuse group, talked with some dread about his scheduled release:

I don't know, I thought I'd be out by now. Out of the last seven years, I've been

"In" five of them, either prison or here. I probably won't make it this time either.

Another member of the group spoke of "busting" back in:

Sure, I know I left without telling anybody and they discharged me and didn't want to take me back in. They were mad 'cause my girl, that they liked, tried to sulcide. That upset me, too. After the doc sald "no," I went out and deliberately ran my car through a tree. Does that sound like a sane man to you? I tell you I need help. I'm doing everything I can on that ward, 
helping Dottie [a blind, disruptive patient] keeping her out of everyone's hair. I think I should get to stay.

The hospital Director spoke about the future:

Trends are changing fast. The patients that are coming to us now are younger, frequently have character disorders. Jall isn't going to do them any good. New programs are going to have to be developed. This is happening throughout the country. 
CHAPTER VII

CONCLUSIONS

Before drawing a set of conclusions and recommendations, some limitations of the study should be considered.

Some limitations of the study center around insufficlent information about employment; e.g., the categories of housewife and student were omitted, possibly skewing the unemployment count. The source of incomes was not explored.

Further IImitations were inadequate definitions of living situations and the omission of queries on marital status. Accurate information about these would have given more insight about the admission-seeker's support system. Future studies might include a number of additional varlables.

The necessity of relying on many and untrained agents for data collection created the potentiality for unverified interpretation and occasional incomplete responses on the questionnaires.

The block sample of two winter months may lead to questions about seasonal differences, the influence of high and seasonal unemployment and possible long-time trends or 
cycles. Valuable information can be gained by a contrast sample of involuntary admissions, and their overlap with the study's sample.

Finally, more sophisticated, multivariate statistical analyses are needed before valid inferences can be sald to be warranted.

Recommendations

Admission duty at Oregon State Hospital is rotated among all staff physicians and residents during the hours of 5:00 p.m. and 8:00 a.m., all day weekends and holidays. Over 50 per cent of the requests for admission come during those hours. This rotation is done in order to give residents experience with the duty and to equalize the load of what is often considered unrewarding and inconvenient work among the staff. It is not usually looked upon as relating to the physician's regular responsibility. This practice is not in the best interest of the patient or the hospital.

Making discriminating decisions regarding admission requests requires specialized skills. These skills, such as crisis counseling and intervention cannot be developed by all the physicians when the duty is shared in short periods of time with many days spaced in between. The decisions to admit need to be based on knowledge of the requesting individuals. In our study 64 per cent of 
the requests came from persons who had been in the hospital less than a year before, and 31 per cent less than two weeks before. Decisions to admit or to deny the admission request also need to be made on a comprehensive knowledge of community resources, especially within the seventy-five-mile radius that included 75 per cent of the individuals in our study .

Finally, the practice of duty rotation makes it impossible to establish common criteria that is consistently interpreted and practiced. Accountability for decision-making is too diffuse when spread among so many people.

It is, therefore, our recommendation that:

1. Specific criteria for admission be established with designated means of review and accountability.

2. A small admission ward be set up with an especially selected and trained staff, including a social worker for family and community liason.

3. Treatment wards be spared the unnecessary work-ups, dislocation of rapid turnover and population swells and thereby enabled to concentrate on treatment, discharge preparation and planning.

4. Individuals accepted into the admission ward will be provided with the appropriate services:

a. Emergency beds for those in crisis. Intervention and counseling services for the requester and/or his family and community. 
b. Temporary shelter for those who have needs inappropriate to other settings but are known or suspected to be disinterested or unavallable for continued treatment and will leave the hospital shortly; our observation established that many individuals are in the hospital only a matter of hours or a few days.

c. Specialized skilis in crisis intervention and counseling, with some followup counseling avaliable if needed for requester and/or his family.

d. Specialized referral to community services when possible.

e. A full range of these services ava1lable between 8:00 a.m. and 11:00 p.m. on weekends and holidays--our study showed 89 per cent of the selfrequests for admission came between those hours.

f. A temporary bed for those coming between $11: 00 \mathrm{p.m}$. and 8:00 a.m.

5. The assignment of individuals to treatment wards will be based on admission work-up collected over the three or four-day period one has been in the admission ward; and that treatment goals and suggestions of method and time line accompany him to the treatment wards.

6. Members of the admission staff work with other agencies in the community to define unmet needs of requesters; work collaboratively with them to change, expand or develop services to meet these needs.

7. This system be tried on an experimental basis, and with the collection of data needed for proper assessment. 
Implications for Further Study and Action

We recommend further study into discharge and followup procedures of hospital patients in order to provide more effective, continuous and comprehensive delivery of service. It became clear in our investigation that many individuals were getting service from other agencies: welfare, community mental health, vocational rehabilitation, alcohol detoxification and rehabilitation, legal ald, jalls, to name a few. The hospital needs to collaborate with these agencies in order to assess exactly what service delivery is ava1lable. Services may need to be expanded, changed, co-opted and developed in order to provide for the contingencies that brought the population in our study to the hospital so often. Some of the services needed by the individuals in our study were:

Crisis service and counseling after 5:00 p.m. on weekends and holidays.

A variety of living, work and recreation situations on a continuum from totally dependent to independent.

Specialized training for staff working in group and nursing homes with mentally/emotionally disordered individuals.

A trained crisis person to go to these homes in case of an emergency.

Day care services.

Home visits. 
A place of retreat for those without resources, who need temporary rest and relief from situational stress, without the stigma of hospitalization or undesired medication.

It is known that different agencies have staff members trained in particular service specialties. Some of these are: crisis counseling, family therapy, assertiveness training, social skill bullding, home management skills, survival skills for independent living, homemaker services, sheltered work situations, body awareness, video assessment or intervention, yoga and play therapy. We suggest that an annotated directory of special resources and staff be compiled. Interagency exchange should be encouraged in order to avold unnecessary duplication and provide greater flexibility and specialization. In many cases the same services are needed by the mentally retarded, emotionally disturbed, alcohol and drug abuser, or newly released prisoner.

This study has examined voluntary admissions to Oregon State Hospital. It is hoped that the knowledge gained here will contribute to understanding the individual and societal needs that underlie the requests for hospitalization. This understanding will make it possible to design more effective services to meet these needs. 


\section{BIBLIOGRAPHY}

Abramson, M. F. "The Criminalization of Mentally Disordered Behavior: Possible Side Effect of a New Mental Health Law," Hospital and Community Psychiatry, Vol. 23, $101-5,1972$.

American Psychiatric Association. Diagnostic and Statist1cal Manual: Mental Disorders, November, 1955.

Blachly, Paul, M.D. "Human Dignity Lost Cause in Commitment Proceedings," The Oregonian newspaper, March 3, 1976.

Bloom, Bernard I. Community Mental Health: A Historlcal and Critical Analysis. New Jersey: General Learning Press, 1973.

Booth, Gene. "Admissions at Oregon State Hosp1tal: 1974," unpublished study, Oregon State Hosp1tal, Salem, Oregon, January, 1975.

Braginsky, Benjamin M. and Dorothea Braginsky. "Mental Hospitals as Resorts," Psychology Today, March, 1973.

Braginsky, Benjamin M., Dorothea Braginsky and Kenneth Ring. Methods of Madness: The Mental Hospital as a Last Resort. New York: Holt, Rinehart and Winston, Inc., 1969.

Bray, J. D. 1973: A Turning Polnt for Mental Health Programs in Oregon. Salem: The Department of Human Resources, 1974 .

Buell, Gregory and W1lliam Anthony. "Demograph1c Characteristics as Predictors of Recldivism and Post Hospital Employment," Journal of Counseling Psychology, 1973, Vol. 20, 361-65.

Burke, A.W. "First Admissions and Planning in Jama1ca," Soclal Psychology, Vol. 91, 1974.

Burling, Edward, Dennis Heath, Tim Jacobs, and Sharyn Kaplan. Deinstitutionalization in Oregon -- A Review of Services Within the Human Resources System. Salem: Department of Human Resources, 1975.

Chesler, Phyll1s. Women and Madness. New York: 1972. 
Crawshaw, Ralph, M.D. "Zoo Animals Better Treated Than Butte 'Psychopaths," The Oregonian newspaper, March 3, 1976 .

Cumming, Elaine and John Cumming. Closed Ranks. Cambridge, Mass.: Harvard University Press, 1957.

Decker, Gary and Allen E. Shealy. "Hospital Admission Rates," Journal of Community Psychiatry, Fall, 1974.

Department of Health, Education and Welfare. Statistical Notes \#81. Washington: 1970.

Di Scipio, W. and G. Commer. "Therapeutic Fallures: Patients Who Return Within Thirty Days of Hospital Discharge," Psychiatric Quarterly, Vol. 47, No. 3, 1973, 371-76.

Eaton, W. W. "Mental Hospitalization as a Reinforcement Process," American Soclological Review, Vol. 39, Apr11, 1974, 252-60.

Fadiman, James and Donald Kewman. Exploring Madness: Experience, Theory and Research. California: Wadsworth Publishing Co., Inc., 1973.

Flomenhaft, Kalman, David M. Kaplan and Donald Langsley. "Avolding Psychiatric Hospitalization," Soclal Work, Vol. 14, October, 1969.

Foucault, Michel. Madness and Civilization: A History of Insanity in the Age of Reason. New York: Random, 1965 .

Franklin, Jack, Lee D. Kittredge and Jean Thrasher. "A Survey of Factors Related to Mental Hospital Readmissions:" Hospital and Community Psychiatry, Vol. 26, No. 11, November, 1975.

Gavee, Kenneth. "Mental Health Division Programs." Salem: Mental Health Division, Oregon State Board of Control, 1961.

Goffman, Erving. Asylums. New York: Anchor Books, 1961. - St1gma. New Jersey: Prentice-Hall, 1963.

Greenblatt, Milton. Dynamics of Institutional Change. P1ttsburgh: University of Pittsburgh Press, 1971. 
Haley, Jay. Strategies of Psychotherapy. New York: Grune and Stratton, Inc., 1963.

. "The Art of Being Schizophrenic," Voices, I $: 133-47,1965$.

Herz, M. D. "The Therapeutic Community: A Critique," Hospital and Community Psychiatry, Vol. 23, No. 3, March, 1972.

Hollingshead, A. and F. Redlich. Social Class and Mental Illness. New York: Wiley, I958.

Howard, Ephraim M. and Joyce I. Howar. "Women in Institutions: Treatment in Prisons and Mental Hospitals," in Women in Therapy: New Psychotherapies for a Changing Society, 357-82. Edited by Violet Franks and Vasant1 Burtle. New York: Brunner/Mazel, 1974.

Hurvitz, N. "Psychotherapy as a Means of Social Control," Journal of Consulting and Clinical Psychology, 40, 232-39, 1973.

Jones, Maxwell. Beyond the Therapeutic Community: Social Learning and Social Psychlatry. New Haven: Yale University Press, 1969.

- The Therapeutic Community. New York: Basic Books, 1963.

Kirsh, Barbara. "Consciousness-Raising Groups as Therapy for Women, "In Women in Therapy: New Psychotheraples for a Changing Society, 326-54. Edited by V1olet Franks and Vasant1 Burtle. New York: Brunner/Mazel, 1974.

Laing, R. D. The Politics of the Family. England: Pathenon, 1971.

Linn, Lawrence. "Social Characteristics and Patient Expectations Toward Mental Hospitalization," Archives of General Psychiatry, Vol. 20, April, 1969, 457-69.

Lore1, T. W. and L. Gurel. "Demographic Characteristics as Predictors of Post Hospital Employment and Readmission," Journal of Consulting and Clinical Psychology, Vol. 40, June, 1973, 426-30. 
Lyle, Jane. Oregonian staff writers. A series of articles on the subject of involuntary commitments, The Oregonian newspaper, January 28-February $28,1976$.

McGarry, A. L. "Law--Medicine Notes: From Coercion to Consent," New England Journal of Medicine, Vol. 274, 1966.

and M. Greenblatt. "Conditional Voluntary Mental Hospital Admission," New England Journal of Medicine, Vol. 287, 1972 .

Maxmen, Jerold S. and Gary J. Tucker. "The Admission Process," Journal of Nervous and Mental Disease, Vol. 156, May, 1973, 327-40.

Mendel, Werner and Sam Rapport. "Determinants of the Decision for Psychiatric Hospitalization, "Archives of General Psychiatry, Vol. 20, March, 1969, 321-24.

Miller, Dorothea H. "Worlds That Fail," Transaction, Vol. 4, No. 2, December, 1966, 38-41.

Nelson, Ann. "Population Pattern Changes," unpublished study, Salem: Oregon State Hospital, 1975.

Olin, G. B. and H. S. Olin. "Informed Consent in Voluntary Mental Hospital Admissions," American Journal of Psychiatry, Vol. 132, No. 9, September, 1975, 938-41.

Rabiner, Charles and Abraham Lurie. "The Case for Psychiatric Hospitalization," American Journal of Psychiatry, Vol. 131, July, 1974, 761-64.

Rosenblatt, A. and J. E. Mayer. "The Recidivism of Mental Patients--A Review of Past Studies," American Journal of Orthopsychiatry, Vol. 44, October, 1974, 697-706.

Rosenhan, D. L. "On Being Sane in Insane Places," Science, Vol. 179, January, 1973, 250-58.

Siegler, Mirlam and Humphrey Osmond. Models of Madness, Models of Medicine. New York: Macmillan Publishing Co., Inc.

Smith; Kathleen, Muriel Pumphrey and Julian Hall. "The Last Straw: The Decisive Incident Resulting in the Request for Hospitalization in One Hundred Schizophrenic Patients," The American Journal of Psychiatry, CXX, September, 1963, 228-33. 
Stancor, H. C., J. A. Sours and Fran Gidro. "Interpersonal Psychodynamics of Voluntary Psychiatric Admissions," Psychiatric Quarterly, 39, Fall, 1965, 516-36.

Szasz, T. S. The Myth of Mental Illness. New York: Hoeber/Harper, 1961.

"Voluntary Mental Hospitalization: An Unacknowledged Practice of Medical Fraud," New England Journal of Mediclne, Vol. 287, May, 1972, 277-78.

Toffler, Alvin. Future Shock. New York, 1970.

Wanklin, J. M., D. F. Fleming, C. W. Buck and G. Hobb. "Factors Influencing the Rate of First Admissions to Mental Hospitals," Journal of Nervous and Mental Disorders, Vol. 121, February, 1955, 103-16.

Welnstein, A. D., D. DI Pasquale and F. Winsor. "Relationsh1p between Length of Stay: In and Out of the New York State Mental Hospitals," American Journal of Psychiatry, Vol. 130, August, 1973, 904-07.

Zwerling, T. Karasu. "A Comparison of Voluntary and Involuntary Patients in a State Hospital," American Journal of orthopsychiatry, Vol. 45, No. I, January, 1975, 81-87. 
APPENDIX 


\section{QUESTIONNAIRE FOR ALL APPLICANTS \\ FOR VOLUNTARY ADMISSION}

1. Date of request

2. Time of day

a.m. (circle)

3. County of residence

4. Sex

5. Age

6. Status of employment: $\square$ Employed $\square$ Unemployed $\triangle$ Disabled

7. Living situation prior to admission request:

7 Independent home $\square$ Nursing home $\square$ other $\triangle$ Parental/Relative home $\square$ Group home

8. Did a particular situation or incident precipitate the admission request? If so, describe:

9. Was the patient referred by:

17 Clinic (specify)

7 M.D.

$\square$ Agency (specify)

$\square$ other (specify) 
10. Who brought the patient for admission?
$\triangle$ Relative
$\square$ Friend
$\triangle$ Police
$\square$ other

11. Does person have access to a bed elsewhere tonight?
$\triangle$ Yes
$\square$ No

12. Had the patient been in contact with any community service or mental health agency just prior to the request?

$$
\square \text { Yes (specify) }
$$

13. Had person been previously hospitalized for psychiatric problems?
$\triangle$ Oregon State Hospital
$\triangle$ Other (specify)
$\triangle$ None

14. If answer to \#13 is affirmative, give the date of the last hospitalization:

15. Approximately how many psychiatric hospitalizations has person had?

16. Has there been treatment other than hospitalization?

$$
\begin{aligned}
& \text { T Private M.D., Clinic, or Counselor } \\
& \text { I Community Clinic or Agency (including drug or } \\
& \text { alcohol) } \\
& \square \text { other (specify) }
\end{aligned}
$$

17. Was the admitting physician familiar with the patient?

$$
\square \text { Yes } \square \text { No }
$$


18. What information source did the admitting physician have?
$\triangle$ Prior chart
$\triangle$ Family member or friend
$\triangle$ Patient
$\square$ Other (specify)

19. Were any collateral contacts made (e.g., clinic, detox, etc.)?

$$
\begin{aligned}
& \square \text { Yes (specify) } \\
& \square \text { No }
\end{aligned}
$$

20. What was the outcome of the admission request?

$$
\begin{aligned}
& \square \text { Admitted } \\
& \square \text { Refused } \\
& \square \text { Refused and referred elsewhere (specify) }
\end{aligned}
$$

21. Screening physician:

22. How did the physician describe the problem? 